\title{
El triunfo sobre la idolatría como victoria sobre el Islam: Nuevas consideraciones sobre el caballero victorioso en el románico hispano
}

\author{
INÉS MONTEIRA ARIAS ${ }^{1}$ \\ The triumph over idolatry as a victory over Islam: new \\ approaches to the iconography of the Victorious Rider in \\ Spanish Romanesque
}

\begin{abstract}
RESUMEN
Este artículo analiza la representación románica del caballero victorioso y su papel en el contexto de la lucha contra el

Islam. Algunos detalles permiten interpretar a la figura derrotada como una representación del musulmán orante, cuya fe era considerada idolátrica. El análisis de la percepción cristiana del musulmán permite relacionar la idea de triunfo sobre

la idolatría evocada por el jinete con la ideología de la guerra sacralizada de la época. Todo ello lleva a la interpretación

de la figura ecuestre, tradicionalmente identificada con Constantino, en un sentido simbólico más amplio y ligado a su contexto político-religioso.
\end{abstract}

PALABRAS CLAVE:

Escultura Románica, Caballero Victorioso, Iconografía guerrera, Islam

\begin{abstract}
This article analyzes the role played by the Romanesque theme of the Victorious Rider in the context of the struggle against Islam. The details of several stone carvings reveal that the defeated figure could represent a Muslim praying as an idolater. In addition, the study of the Christian perception of Muslims demonstrates the connection between the Crusader's ideology and the notion of the defeat of idolatry evoked by the Horseman. Therefore, the identity of the Rider itself, who has been traditionally considered as Constantine, can be understood in a more general and symbolic sense according to the religious and political contexts.
\end{abstract}

\section{KEYWORDS}

Romanesque Sculpture, Victorious Rider, War Iconography, Islam

\footnotetext{
${ }^{1}$ Departamento de Historia del Arte, Facultad de Geografía e Historia (UNED); Despacho 1, Ext. 6787. Paseo Senda del Rey, 7. 28040 Madrid. imonnteira@geo.uned.es
} 


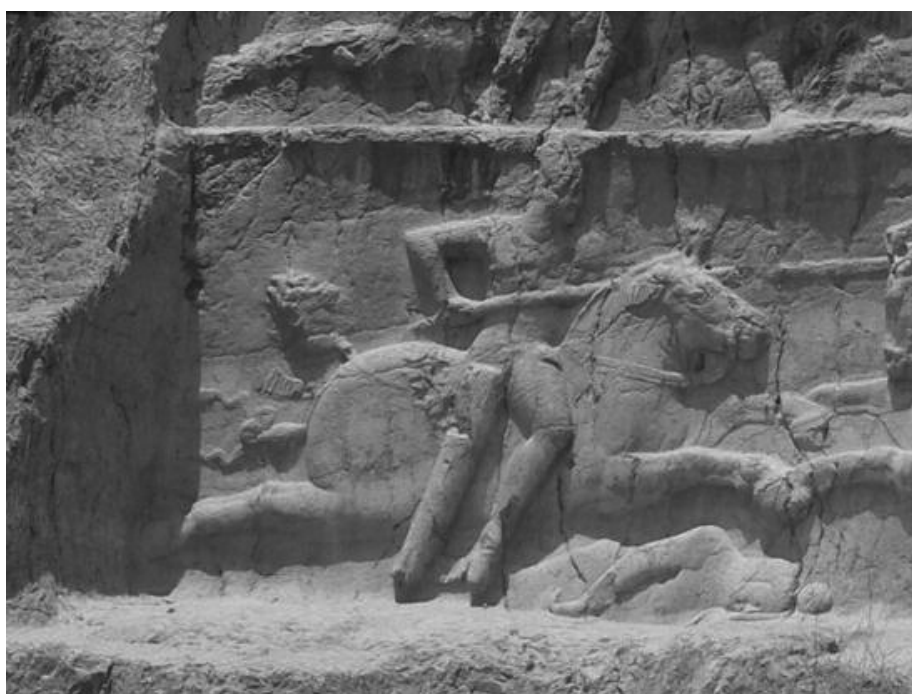

Figura. 1. Victoria del rey Bahram II sobre un enemigo situado junto a la tumba de Darío el Grande, c. 274-294 d. C. Valle de Naqs-i Rustan, inmediaciones de Persépolis, Irán. Fotografía: I. Monteira.

La representación del caballero glorificado que aplasta a un enemigo con las patas delanteras de su caballo es una imagen frecuente en la escultura románica y ha llamado desde antiguo la atención de los historiadores del arte. A pesar del gran número de publicaciones existentes sobre este tema, los diversos ejemplos conservados presentan variaciones que ofrecen claves interpretativas aun por estudiar. La capacidad del caballero victorioso de simbolizar el triunfo sobre el Islam en el territorio hispano durante los siglos centrales de la Edad Media -ya apuntada por algunos especialistas- puede ser ratificada y enriquecida mediante el estudio de algunos relieves combinado con el análisis de la percepción del musulmán entre los cristianos de aquel tiempo. A lo largo de estas páginas se recogerán las principales interpretaciones ofrecidas sobre el asunto y se analizará la idea de triunfo sobre la idolatría evocada por el tema iconográfico, así como el modo en que dicha noción pudo ser puesta al servicio de la ideología de la guerra contra el Islam. Por otro lado, se profundizará en el estudio de la figura derrotada, la cual ha recibido menos atención que el caballero por parte de la historiografía.

El tema del caballero victorioso experimenta un enorme auge en tiempos plenomedievales y en la escultura románica, pero no carece de precedentes figurativos. Desde la Antigüedad, las figuras del héroe y el soberano han sido representadas en actitud triunfal sobre un caballo que apoya sus cascos en el enemigo vencido, por lo que el origen formal del tema románico es remoto. Entre las representaciones más antiguas se cuentan las del arte rupestre sasánida del valle de Naqs-i Rustan (Irán, inmediaciones de Persépolis), donde los relieves que decoran las tumbas de los príncipes aqueménidas muestran al soberano cabalgando sobre 
un romano derrotado, como se observa en la escena de la Victoria del rey Bahram II (Figura 1). Los romanos representaron igualmente a sus emperadores ecuestres y triunfantes sobre los enemigos vencidos, imagen que se relaciona con la $\mathrm{Ad}$ ventus -entrada triunfal del emperador en la ciudad-y que permanece hasta las postrimerías del Imperio(1).

También las ilustraciones medievales de la Psychomaquia de Prudencio presentaron algunas similitudes con el tema del caballero victorioso, al encarnar la Soberbia por medio de una figura tendida bajo el caballero, o bien caída del cabaIlo(2). No obstante, asistimos a un cierto vacío en la representación del caballero triunfante en la primera mitad de la Edad Media, lo que hace aun más notable el vigor con que resurge en el arte románico francés y español.

Las razones de esta repentina y profusa reaparición fueron estudiadas desde muy pronto por los historiadores del arte, intrigados por la identidad del caballero(3). Fue el eminente historiador Émile Mâle quien ofreció una identificación que fijaría durante largo tiempo la tesis comúnmente aceptada. Según Mâle, era Constantino el Grande quien aparecía en los relieves románicos como vencedor sobre el paganismo, encarnado éste en el pequeño personaje derrotado a sus pies(4). La identificación del caballero como Constantino I se amparaba en su supuesta popularidad durante los siglos del románico entre los peregrinos retornados de Roma, quienes contemplaron la estatua del Emperador frente al palacio papal de Letrán. Se trataba, en realidad, de la estatua ecuestre de Marco Aurelio (Figura 2), situada entonces sobre la figurita de un bárbaro y tenida erróneamente por Constantino(5). Diversos historiadores siguieron a Mâle en la identificación de los caballeros victoriosos franceses, aludiendo a la posible existencia de plomos traídos por los peregrinos con la imagen del emperador ecuestre como prueba perdida de la migración del tema iconográfico a tierras septentrionales(6).

No obstante, algunos de los argumentos esbozados por estos autores han ido perdiendo vigor con las nuevas investigaciones. El documento más importante evo-

(1) Como se observa en el Marfil Barberini, Museo del Louvre (París), c. 500. No obstante, en éste, el cónsul apoya su pie sobre una personificación de la Tierra que subraya su poder y prosperidad, mientras el enemigo persa aparece tras su lanza. Imagen en alta resolución en http://musee.louvre.fr

(2) SEIDEL, L. Songs of Glory. The Romanesque Façades of Aquitaine. Chicago y Londres, Universidad de Chicago, 1981, p. 56; NORMAN, J. S. Metamorphoses of an Allegory. The Iconography of the Psychomachia in Medieval Art. Nueva York, American University Studies, Peter Lang, 1988, p. 55.

(3) Concretamente desde 1840. Historiografía resumida por CROZET, R. «Le thème du cavalier victorieux dans I art roman de France et d Espagne», Príncipe de Viana, no 124, 1971, pp. 125-144.

(4) MÂLE, E. L Art Religieux du XIle siècle en France. Étude sur les origines de I iconographie du Moyen Âge, París, Armand Colin, 1966, pp. 247-251; la primera edición fue en 1922. Hasta entonces el caballero había sido interpretado como San Jorge o Pipino el Breve; ĺdem., p. 248.

(5) Ídem., pp. 247-251; APRAIZ, A. «La representación del caballero en las iglesias de los Caminos de Santiago», Archivo Español de Arte, 46, 1941, p. 386.

(6) Como Adhémar respecto al tímpano de Parthenay-le-Vieux ; ADHEMAR, J. Influences Antiques dans I art du Moyen Âge en France. Londres, Warburg Institute, 1939, pp. 207-216. Si bien Mâle ya realizaba esta interpretación en Partheny, MÂLE, E. Op. Cit. p. 248. 


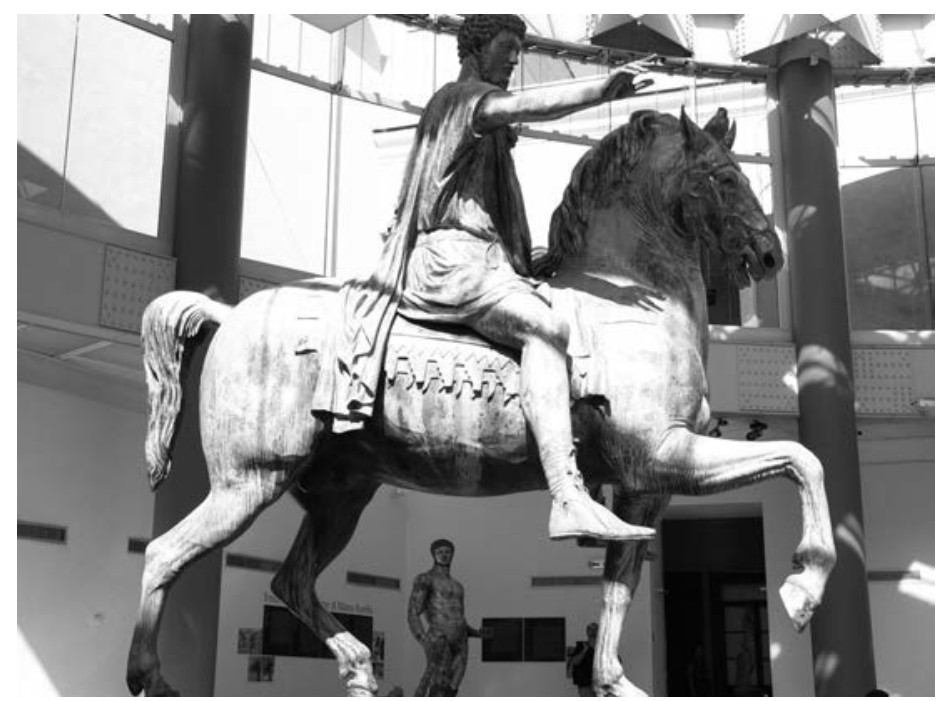

Figura. 2. Estatua de Marco Aurelio, 153 d. C., Museos Capitolinos, Roma. Fotografía: I. Monteira.

cado por Mâle para demostrar esta identificación era la carta escrita en 1148 por un tal Guillermo David que pedía ser enterrado «sub Constantino de Roma qui locus est ad dexteram partem ecclesiae» de la abadía Aux-Dames de Saintes (CharenteMaritime, Francia)(7). Una mala traducción, según Crozet, llevó a pensar que «locus est ad» se refería a «situado a», mientras «locus» debía ser traducido como «sepultura». Este autor indicaba, además, que una referencia a la estatua de Constantino tendría que haber ido acompañada de palabras como statua, imago, imperator, magnus, etc. De este modo, Crozet negó que el texto hiciera referencia al relieve del caballero de la abadía de Saintes, indicando que sólo reflejaba la voluntad de un particular de ser enterrado junto al sarcófago de un tal Constantino de Roma, cuyo nombre permanece en una inscripción de la iglesia junto a una sepultura(8).

Por su parte, Kingsley Porter explicaba la elaboración del tema del caballero románico a partir de la influencia de una iconografía constantiniana bizantina hoy perdida, y con independencia de la estatua de Marco Aurelio, ofreciendo una

(7) MÂLE, E. Op. Cit. p. 248; Antes que Mâle, el abad Grasilier había publicado el texto que hallara en el cartulario de la abadía, relacionándolo con la imagen del caballero; CROZET, R. «Nouvelles remarques sur les cavaliers sculptés ou peints dans les églises romanes», Cahiers de Civilisation Médiévale, Xe-XIle siècles, I 1, 1958, pp. 31-32.

(8) CROZET. R. Op. Cit. 1958, p. 31. Esta inscripción mal interpretada constituía el argumento más consistente para defender la identificación del Constantino histórico, llegándose a interpretar la figura femenina como su esposa Fausta y al vencido con Maximino. Otros ejemplos franceses han sido evocados para defender la tesis constantiniana, como el mosaico de Riez en Peiresc donde un caballero victorioso es identificado como Constantino por una inscripción (CONSTANTINUS LEPROSUS), siendo ésta la prueba más convincente de la identificación como el emperador romano, según Crozet, si bien se trata de un mosaico hoy perdido; ĺdem., p. 32. 
identidad para la figura femenina que acompaña en ocasiones al caballero: la de la emperatriz Elena(9). Otros autores incidieron en el influjo señorial de esta representación, asociándola con los poderes laicos en un sentido amplio(10).

La identificación de Constantino ha sido así la más generalizada en la historiografía en lo que se refiere al románico francés(11), aunque diversos trabajos han rebatido esta identificación. Linda Seidel fue pionera en la crítica a los abusos interpretativos desplegados en torno a esta figura por haberse llegado a asignar la identidad de Constantino a todos los caballeros victoriosos franceses y la cuestionó fuertemente, dudando de la existencia de un verdadero culto al primer emperador cristiano en época plenomedieval(12). De igual modo señalaba que, si la imagen sólo se podía explicar en virtud del modelo romano, resultaba contradictorio que ésta no apareciera en regiones adyacentes a Italia y sí en el camino jacobeo.

Por otro lado, varios autores han preferido ver en la imagen románica la representación de Carlomagno, quien había encargado un retrato ecuestre muy similar al del primer emperador cristiano, cuyo modelo en miniatura conservamos aun en el Museo del Louvre(13). La propia Seidel defendía esta relación, indicando que el tema escultórico aparece en iglesias ubicadas precisamente en los lugares donde la leyenda sitúa las batallas del emperador franco contra los musulmanes: occidente francés, Provenza y norte de España(14).

Las interpretaciones de los ejemplos registrados en el románico español han variado notablemente respecto de las ofrecidas para los casos septentrionales, pues ha prevalecido la idea de la lucha contra el Islam, independientemente de la identidad del caballero. Inicialmente, los historiadores coincidieron en que se trataba de la representación de Santiago Matamoros(15). Esta teoría, lue-

(9) El modelo estaría fijado por un mosaico, hoy perdido, del Santo Sepulcro de Jerusalén, donde aparecía Constantino con la emperatriz Elena, la cual habría condicionado la aparición de una figura femenina junto al caballero; KINGSLEY PORTER, A. Romanesque sculpture on the Pilgrimage Roads, Vol. I, Boston, M. Jones, 1923, p. 187.

(10) LABANDE-MAILFERT, Y. «L Iconographie des laïcs dans la société religieuse aux VIo et XII siècles", en I Laici nella societas christiana dei secoli XI e XII. Atti della Terza Settimana Internazionale di Studio, Universita cattolica del Sacro Settimana internazionale di studio, Mendola, 1965, pp. 488-529.

(11) También la defienden WEISBACH, W. Reforma religiosa y arte medieval: la influencia de Cluny en el románico occidental, Espasa-Calpe, Madrid, 1949, p. 29; e Y. Labande Mailfert, Op. Cit. 1965, p. 488 , entre otros.

(12) SEIDEL, L. «Constantine «and» Charlemagne», Gesta, XV, 1-2, 1976, p. 237; L. Seidel «Holy Warriors. The Romanesque Rider and the Fight Against Islam», en The Holy War. Ed. T. P. Murphy, Ohio State University Press, Columbus, 1976, pp. 33-34.

(13) Actualmente, la estatuilla se atribuye a Carlomagno o a Carlos el Calvo y se data en el s. IX, aunque tiene añadidos de restauración del s. XVIII, y carece de enemigo vencido a los pies. Disponemos de una imagen detallada online en http://www.louvre.fr (Collection/ Overview/ Curatorial Departments/ Decorative Arts/Selected Works/5)

(14) SEIDEL, L. Op. Cit. «Holy Warriors...» pp. 39-40.

(15) CROZET, R. Op. Cit. 1958, p. 34; Así lo hizo por primera vez Ángel de Apraiz, al considerar que estas imágenes en el camino de Santiago han sido popular y tradicionalmente tenidas por Santiago matamoros. APRAIZ, A. Op. Cit., pp. 384-396, apareciendo en iglesias de advocación jacobea. Porter relaciona algunos relieves franceses con Constantino y su madre Elena, indicando respecto a los españoles que Santiago adopta la forma de caballero victorioso, K. PORTER, op. cit., Vol. I, p. 187. 


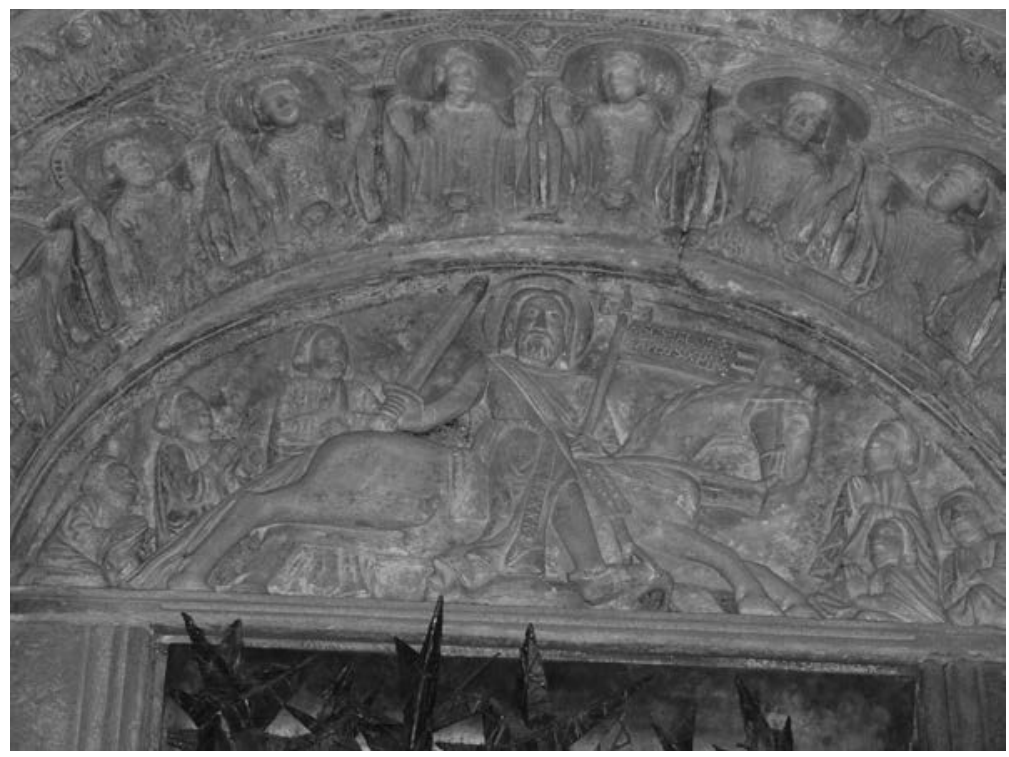

Figura. 3. Tímpano de la puerta del Tesoro de la Catedral de Santiago de Compostela, datado a finales del s. XII ó c. 1220. La Coruña. Fotografía: I. Monteira.

go cuestionada, tomaba como referencia el tímpano de la puerta del tesoro de la Catedral de Santiago(16) (Figura 3), en el crucero sur, donde el apóstol, identificado por una inscripción aparece, con su cruz y su espada, conforme a la leyenda de la batalla de Clavijo (834), aunque sin enemigo a sus pies. Las figuras femeninas tras él recuerdan que su intervención puso fin al deshonroso tributo de entregar anualmente cien vírgenes cristianas a los moros(17). La claridad con que se reconoce a Santiago en este tímpano llevó a la identificación de todos los caballeros victoriosos hispanos como la imagen del apóstol guerrero, en lugar del emperador romano(18). La tradición también contribuyó a interpretar como Santiago al caballero triunfante en lugares como Armentia (Vitoria) (Figura 4), donde el apóstol aparecía también en el retablo principal de la basílica, y en la portada

(16) Fechado en el s. XII por GARCÍA PÁRAMO, A. «La iconografía de Santiago en la pintura gótica castellana», Cuadernos de Arte e Iconografía, Tomo IV-11, 1993, http://www.fuesp.com/revistas/pag/ cai1109.htm, sin paginar; y en 1220 por MÁRQUEZ VILLANUEVA, F. Santiago: trayectoria de un mito. Bellaterra, Barcelona, 2004, p. 184 y SICART GIMÉNEZ, A. «La iconografía de Santiago ecuestre en la Edad Media», Compostellanum, 1-2, 1982, p. 28.

(17) El relato más antiguo de esta leyenda es el Privilegio de los Votos, que suele datarse a finales del s. XI atribuirse al canónigo Marcio; CABRILLANA CIÉZAR, N. Santiago Matamoros, historia e imagen. Diputación de Málaga. Málaga, 1999, p. 74. Otros le conceden una cronología posterior, llevándoselo a mediados del s. XII. Sobre la identificación del tímpano con este pasaje, CROZET, R. Op. Cit. 1958, p. 34; MÂLE, E. Op. Cit., p. 297. Sicart sugiere que no se trata de las doncellas, sino de los combatientes en adoración ante la aparición del Santo, SICART GIMÉNEZ, A. Op. Cit. p. 29.

(18) APRAIZ, A. Op. Cit., 384-396; RUIZ MALDONADO, M. El Caballero en la escultura románica de Castilla y León. Salamanca, Universidad de Salamanca, 1986, pp. 13-24. 


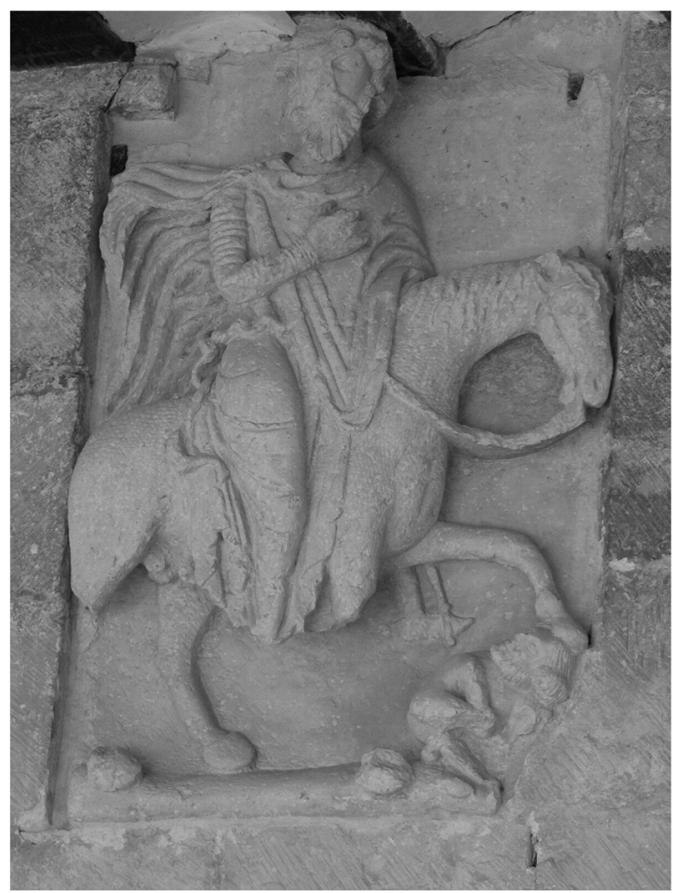

Figura. 4. Relieve exterior de la fachada sur de la basílica de San Prudencio, Armentia, Vitoria, Álava. Fotografía: I. Monteira.

de la iglesia de Sta. María de Carrión de los Condes(19)(Palencia)(Figura 5). Pero sólo tenemos evidencias del surgimiento de la imagen del Matamoros a inicios del s. XIV(20) y, a pesar de que su efigie está profundamente ligada a la del caballero victorioso, no podemos hablar del Matamoros hasta esa fecha, aunque sí de Santiago. Lo cierto es que la imagen del apóstol triunfando sobre los musulmanes ha perdurado hasta el siglo pasado en la figura de un caballero que aplasta con su cabalgadura a los infieles derrotados y decapitados(21). Además, estas representaciones aparecen prioritariamente en el románico del camino de Santiago. Por ello, y a pesar de que la identificación jacobea resulta hoy controvertida, sí resulta evidente la importancia del contexto de la lucha contra el Is-

(19) APRAIZ, A. Op. Cit., p. 390; RUIZ MALdOnADO, M. Op. Cit., pp. 13-24. No obstante, Mª Flora Cuadrado esboza varias identificaciones simultáneas para esta figura: Constantino, un «caballero laico», una imagen de función apotropaica, o bien, carente de significado; CUADRADO LORENZO, M" F. «La iglesia de Santa María del Camino de Carrión de los Condes y su programa escultórico», Publicaciones de la Institución Tello Téllez de Meneses, 57, 1987, pp. 250-251.

(20) La primera representación clara de Santiago Matamoros aparece en el Tumbo B de la Catedral de Santiago de Compostela en 1326, donde lo encontramos bajo el título de miles christ; LÁZARO DAMAS, M. S. "Una iconografía de frontera: Santiago Matamoros en el Privilegio de Pegalajar», Sumuntán, no 15, 2001, p. 52.

(21) Un estudio monográfico en CABRILLANA CIÉZAR, N. Op. Cit. 


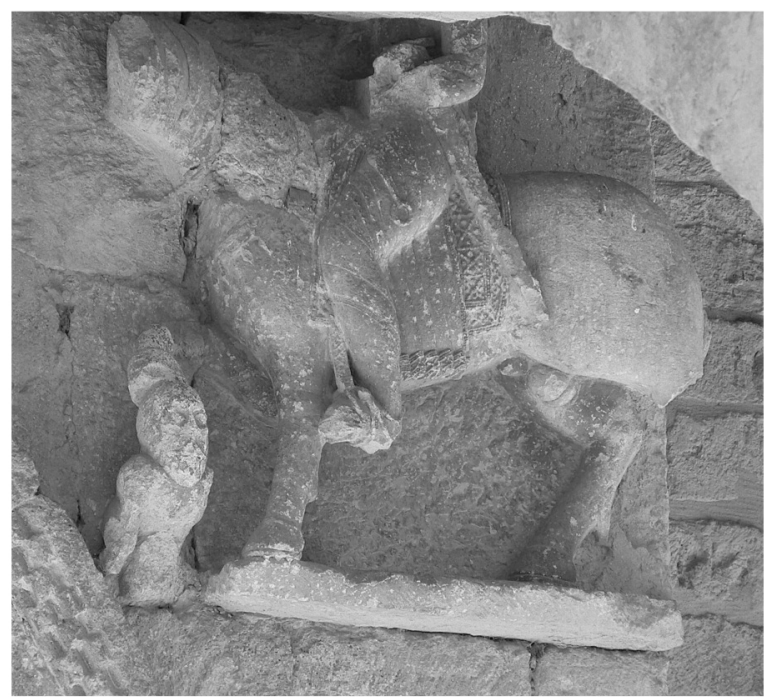

Figura. 5. Relieve de la portada de la iglesia de Santa María de Carrión de los Condes, mediados del s. XII, Palencia. Fotografía: I. Monteira.

lam para la proliferación de la imagen románica, entendida mayoritariamente en nuestras tierras como emblema del combate antiislámico(22).

No obstante, la conexión del tema del caballero victorioso en el románico hispano con el contexto de la lucha contra el Islam se ha hecho de modo vago, sin aportar más pruebas que la evidente importancia de la Reconquista y la ausencia de referencias a Constantino en el Camino de Santiago. Además, también se ha llegado a defender la identificación jacobea para algunos ejemplos franceses, dado que son relieves situados en esta ruta y no en la vía de peregrinación romana(23). Rita Lejeune y Jacques Stiennon señalaron que la imagen del caballero sobre un cuerpo enemigo, generalmente desnudo, no representaba otra cosa que la victoria sobre los musulmanes, inclinándose prioritariamente por la identificación de Carlomagno(24). De este modo, con frecuencia el tema ha acabado interpretándose prioritariamente en un sentido amplio como la alusión genérica al triunfo sobre el Islam y, en consecuencia, también como la derrota del infiel lujurioso, cuando el vencido presenta unos inmensos genitales, en correspondencia con las nociones habitualmente atribuidas a los musulmanes por aquél tiempo(25). La

(22) SICART GIMÉnEZ, A. Op. Cit., pp. 11-32; Ruiz Maldonado, M. Op. Cit. pp. 13-24.

(23) APRAIZ, A. Op. Cit. pp. 384-396.

(24) En un ejemplar ilustrado del Roulantes Liet alemán de mediados del s. XII, el caballero triunfante junto a una mujer y una ciudad fortificada representan la entrada de Carlomagno en Zaragoza cuando la reina de la ciudad, Bramimonde, se convierte al cristianismo, LEJEUNE R. y STIENNON, J. The Legend of Roland in the Middle Ages, Londres, Phaidon, 1971, Vol. I, p. 134, Vol. II Figura 126A.

(25) SEIDEL, L. Op. Cit. 1981, p.67, respecto al tímpano de la iglesia de la Rochette. Esta alusión al infiel lujurioso formaría parte, para la autora, de un juego de doble dimensión simbólica característico del románico, que permite referirse al triunfo de la virtud sobre el vicio al tiempo que al del cristianismo sobre 
indumentaria del vencedor inspirada en los caballeros plenomedievales ha sido igualmente subrayada por la historiografía como indicio de la adscripción a su propia época de combate antiislámico(26). En este sentido, ha resultado muy relevante la presencia de la figura del caballero victorioso en contextos iconográficos de propaganda de las cruzadas, ya que la lucha contra el Islam no fue asunto exclusivo del ámbito peninsular, sino de toda la cristiandad occidental. Deschamps sería el primero en localizar el tema en un capitel románico de arte cruzado -desarrollado por los pobladores cruzados del Próximo Oriente- procedente de Jerusalén. Éste presenta un caballero coronado y con espada sobre un personaje desnudo y encogido a los pies de su caballo. Vencedor y vencido aparecen junto a unas puertas de ciudad y frente a una figura femenina provista de un ramo florido(27). Sin descartar la tesis constantiniana, Deschamps propuso la identificación como un caballero cruzado triunfando sobre el Islam y honrando a la Iglesia, que se encarna en la figura femenina. Esta teoría, según la cual el antiguo tema imperial había evolucionado para adaptarse al contexto coetáneo de lucha contra los musulmanes, venía a equiparar el relieve de arte cruzado con las representaciones hispanas. Más recientemente, Curzi ha analizado la presencia del caballero triunfante en la Capilla templaria de Cressac -suroeste de Francia, segunda mitad del s. XII -, donde los frescos presentan todo un programa figurativo de la Segunda Cruzada. Aunque el autor interpreta esta figura como Constantino, señala que su función fue la de servir de alegoría de la guerra contra los musulmanes, evidenciada tanto por la flor de lis que identifica al caballero con la monarquía francesa como por la figura del infiel a sus pies, que vienen a acompañar la escena de batalla contra las tropas de Nur al-Din, situada en un muro adyacente(28). De este modo, las pruebas esgrimidas para defender la función antiislámica del tema en al-

el Islam. Respecto a la imputación de lujuria a los musulmanes, puede consultarse el trabajo clásico de DANIEL, N. Islam et Occident. París, Les Éditions du Cerf. 1993, múltiples referencias a fuentes plenomedievales en pp.185-192. Sobre su repercusión en el arte románico ver MONTEIRA ARIAS, I. «Las formas del pecado en la escultura románica castellana. Una interpretación contextualizada en relación con el Islam», Codex Aquilarensis, 21, 2005, pp. 48-87.

(26) Varios autores han llamado la atención sobre el hecho de que, con frecuencia, el caballero lleva una armadura medieval que permite adaptar el tema a las circunstancias del momento, WEISBACH, W. Op. Cit. p. 29; CROZET, R. Op. Cit. 1971, pp. 125-144; RUIZ MALDONADO, M. Op. Cit., pp. 13-24. La «actualización» del armamento de los asesinos de los Testigos en ilustraciones del pasaje apocalíptico de diversos manuscritos europeos del s. XIII ha sido también interpretado como un indicio de adaptación de las imágenes bíblicas al contexto ideológico de la lucha antiislámica, dado que es con armadura y armas características de los musulmanes como los verdugos aparecen; WRIGHT, R. M. Art and Antichrist in Medieval Europe, Manchester y Nueva York, Manchester University Press, 1995, pp. 153-154, 174. Por su parte, Wirth habla de la vestimenta que actualiza los pasajes, tendencia que señala intensa a partir de 1100 «Cette modernisation fait allusion au présent, soit pour le critiquer, soit pour situer dans I actualité une iconographie morale... soit encore pour faire un parallèle entre I attente de la venue du Christ par les prophètes et celle de la seconde venue $d$ aujourd'hui» con el fin de oponer de modo simplificado lo temporal a lo intemporal ; WIRTH, J. L image à l époque romane, París, Les éditions du Cerf, 1999, p. 246.

(27) DESCHAMPS, P. «La sculpture française en Palestine et en Syrie», Monuments Piot, XXXI, 1930, pp. 94-95. Sus teorías son secundadas por RUIZ MALDONADO, M. Op. Cit. pp. 13-24.

(28) CURZI, G.»Cavalieri in battaglia: le pitture murali della cappella di Cressac», Art et Dossier, 196, 2004, pp. 45-46. 
gunos ejemplos del románico francés han sido, incluso, más consistentes que en el ámbito hispano -aunque son aplicables al mismo.

Por último, y en lo que a posturas historiográficas se refiere, conviene destacar uno de los aspectos más importantes de la simbología de esta representación que aún no ha sido mencionado: su referencia al triunfo sobre la idolatría. La idea del triunfo de la fe sobre el paganismo y la idolatría es un aspecto repetido desde las primeras tesis planteadas a lo largo del tiempo(29). Esta teoría deriva del propio simbolismo de Constantino como defensor de la Iglesia ante el antiguo paganismo, pero merece ser analizada en detalle para el contexto medieval, donde el fantasma de la antigua idolatría permanece con fuerza. Dicho análisis revela que la idea de la idolatría derrotada no está reñida con la del triunfo sobre el Islam, sino que ambas nociones coexistieron e interaccionaron en el imaginario cristiano del momento, como veremos.

En todo caso, se observa que los elementos comunes a las distintas teorías desarrolladas en torno a la figura del caballero victorioso se refieren más a su simbología que a su identidad, cuya interpretación ofrece más controversias. De hecho, lo que resulta esencial para comprender esta representación es la función que cumplió, la razón que impulsó a situarla en tantas iglesias y los valores que encarnó para los fieles de su tiempo. Por ello, la cuestión de si se identificaba eventualmente con un personaje concreto queda relegada a un segundo plano ante la evidencia de que constituye una figura alegórica, de simbolismo generalizador, capaz de encarnar la victoria sobre el Islam o bien el triunfo sobre la idolatría. La ausencia de inscripciones aclaratorias -presentes en otras representaciones como la del Tesoro de la Catedral de Santiago (Figura 1)- ratifican las connotaciones generalizadoras de la figura o, al menos, la preeminencia de las mismas sobre su identidad individual.

No obstante, la alusión a la idolatría vencida por la representación del caballero victorioso resulta, a priori, un poco confusa si la inscribimos en el contexto de la guerra contra el Islam, pues sabemos que las tres religiones del Libro fueron particularmente hostiles hacia la antigua adoración de estatuas. Por ello, resulta pertinente y necesario preguntarse por lo que representaba la idolatría para quienes elaboraron y contemplaron los programas iconográficos románicos, antes de poder determinar si el personaje vencido bajo el caballero hizo referencia a los adoradores de imágenes y dioses.

Si rastreamos en los escritos de la época las nociones aparejadas a la idolatría -especialmente en textos monásticos, eclesiásticos y cronísticos, redactados en los mismos círculos desde los que se llevó a cabo la edificación de templos románi-

(29) ADHEMAR, J. Op. Cit. pp. 214-215; MÂLE, E. Op. Cit. p. 250.

(30) DUCELLIER, A. Le Miroir de I Islam. Musulmans et Chrétiens d Orient au Moyen Age (VII-XI siècle). Mesnil-sur-I Estrée, Julliard, 1971, pp. 30-31. También lo fue por los monjes mozárabes que escribieron contra las autoridades de al-Andalus; SÁEZ, J. M. El movimiento martirial de Córdoba. Notas so- 
cos-, podremos interpretar mejor la figura vencida por el caballero y, en definitiva, interpretar la representación en su contexto histórico y de mentalidad. Este recorrido permitirá demostrar que la referencia de la figura derrotada a los musulmanes resulta compatible con las nociones aparejadas a la idolatría del antiguo paganismo. Veremos además que numerosos textos ofrecen descripciones de los musulmanes que se aproximan enormemente a las figuras situadas bajo los caballeros románicos, permitiendo alegar pruebas textuales y figurativas para su identificación.

La literatura cristiana occidental de refutación y combate doctrinal contra el Islam construyó una imagen de los musulmanes que, en algunos aspectos, los equiparaba con los antiguos paganos, siendo «pagano» un calificativo habitual de la época empleado para los musulmanes(30). La equiparación del Islam con el antiguo paganismo se hizo especialmente notable en lo que se refiere a la atribución de prácticas idolátricas a los sarracenos en los textos latinos. Ya Eulogio y Álvaro de Córdoba, autores polémicos mozárabes de mediados del s. IX, apuntaban a la supuesta idolatría de los musulmanes en sus ritos(31), aspecto resaltado también en el Pasionario Hispánico, que se refiere al culto de Venus en el mundo islámico(32). Las crónicas hispanas de la Reconquista también denominaron idólatras a los enemigos religiosos, inventando falsos dioses a los que se encomendaban antes de la batalla(33). Otros autores, como Pedro Alfonso en el s. XII, se refirieron a

bre la bibliografía. Universidad de Alicante, http://www.ua.es/personal/jms/hc/mov_martirial.PDF. Alicante, 2006, p. 91; por los cronistas hispanocristianos de la Reconquista y por los de las cruzadas: BARKAI, R. Cristianos y musulmanes en la España medieval (El enemigo en el espejo). Madrid, Rialp, 1984, p. 157; así como por los autores francos cluniacenses; D ALVERNY, M. Th. «Deux traductions latines du Coran au Moyen Âge", Archives d Histoire Doctrinale et Littéraire du Moyen Âge, 1947-1948, $\mathrm{XVI}$, pp. 69-131; y, finalmente, en los cantares de gesta ; BANCOURT, P. Les Musulmans dans les Chansons de Geste du Cycle du Roi. II Vol. Université de Provence, Marsella, 1982, Vol. I, p. 342. J. Tolan ha puesto de manifiesto que la atribución de idolatría a los musulmanes depende en gran medida de su completa asimilación con el antiguo paganismo; J. V. TOLAN, Sarracenos. El Islam en la imaginación medieval europea. Universidad de Valencia, Valencia, 2007, pp. 163-164.

(31) Eulogio recogía el Salmo 96, 7, contra la idolatría para emplearlo contra los musulmanes: «Sean confundidos todos los que adoran ídolos y los que se glorían con estatuas», EULOGIO DE CÓRDOBA, Obras completas de San Eulogio. Trad. y Ed. Ma Jesús Aldana García. Córdoba, Universidad de Córdoba, 1998; Apologeticus Martyrum, 19, p. 202. Mientras Álvaro de Córdoba indicaba «entregados a su rito, aquellos días en que consagran su desenfreno en el templo del ídolo]...[Adoran, pues, hasta hoy a Maozim en su santuario, como el profeta declaró por inspiración divina», ÁLVARO DE CÓRDOBA, El Indiculus Luminosus. Álvaro de Córdoba y la Polémica contra el Islam, Ed. Delgado León, Feliciano. Córdoba, CajaSur, 1996, Indiculus Luminosus, 25, pp. 150-151. Se refería también a la antigua idolatría del pueblo árabe: «puesto que todos estaban inficionados por el cieno de la gentilidad y de la idolatría, [Mahoma] hallándolos vacíos los devoró y los ligó a sí con vínculo perpetuo », Ídem., Indiculus Luminosus, 26, pp. 154-155.

(32) La narración del martirio de Nunilón y Alodia compuesta en el s. IX, decapitadas por apostasía al declararse cristianas siendo hijas de padre musulmán, hace referencia a la antigua idolatría del pueblo árabe que se rendía y aun rinde al culto de Venus; Pasionario Hispánico. Estudio y Ed. P. Riesco Chueca, Sevilla, Universidad de Sevilla, 1995, pp. 288-289.

(33) Así lo vemos en el Poema de Almería, que narra la toma de esta ciudad en 1147 y se indica respecto a los musulmanes «Como adoran a Baal, Baal no los libera»; «Cum colunt Baalim, Baalim non liberat illos.»; siendo Baal un ídolo veterotestamentario adorado por el nefasto pueblo de los madianitas, Poema de Almería, v. 14, en Chronica Adefonsis Imperatoris, Ed. L. Sanchez Belda. Madrid, CSIC, 1950, pp. 166 y 188, otra referencia en v. 289, pp. 182 y 202. 
la ritualidad musulmana como idolátrica, amparándose en aspectos reales como la veneración de la Kaaba en La Meca(34).

Los textos de origen franco fueron aún más insistentes y exagerados en la imputación de idolatría a los musulmanes. La Historia de Carlomagno incluida en el Códice Calixtino (c. 1130), cuenta que el emperador destruyó las imágenes y los ídolos musulmanes en Hispania(35), indicando que los paganos tenían un ídolo de Mahoma que era irrompible por un conjuro del demonio(36). Otros autores cluniacenses como Pedro el Venerable insistieron en la idolatría del enemigo en sus escritos de refutación religiosa(37). Pero es en las crónicas de la primera cruzada donde la noción de los musulmanes como idólatras aparece más repetida, llegándose a hacer descripciones pormenorizadas de la apariencia de dichos ídolos supuestamente contemplados por los cronistas(38). Esto lleva a suponer que estas nociones fueron difundidas de manera intencionada como propaganda de la guerra sacralizada emprendida contra los musulmanes peninsulares y orientales.

Conviene añadir que las descripciones latinas de los musulmanes, por disparatadas que fueran, se ampararon con frecuencia en aspectos reales que les otorgaron mayor verosimilitud y facilitaron su divulgación tanto entre los cristianos que no tuvieron contacto con los musulmanes, en la Europa septentrional, como en las zonas donde existió una convivencia, en amplias regiones de la península ibérica. Aunque la imputación de idolatría a los musulmanes se fundamentó inicialmente en la adoración de las dos piedras albergadas por la Kaaba en La

(34) Y de las piedras que ésta contiene. El judío converso Pedro Alfonso escribe a principios del s. XII en la Zaragoza de Alfonso I un Diálogo contra los Judíos, dedicando el capítulo V a refutar el Islam; PEDRO ALFONSO DE HUESCA, Diálogo contra los Judíos, Intro. John V. Tolan. Huesca, Instituto de Estudios Altoaragoneses, Larumbe. 1996, V, pp. 295, 299-300.

(35) Liber Sancti Jacobi. Codex Calixtinus. Trad. A. Moralejo, C. Torres y J. Feo. Xunta de Galicia, Santiago, 2004, Libro IV, Historia de Turpín, Cap. IV, p. 427, donde se habla de Carlomagno como héroe y responsable de la Reconquista española y se cuenta como llega a Cádiz para destruir los ídolos de los musulmanes, la frase textual es muy expresiva: «...nosotros creemos en el Padre, el Hijo y el Espíritu Santo y los adoramos. En cambio, vosotros creéis en el diablo y veneráis a estatuas».

(36) Este representaba un gran peligro para los cristianos que a él se acercaban y era tan pernicioso que los pájaros que sobre él se posaban morían; Esta y otras descripciones en CARLETON MUNRO, D. «The Western Attitude toward Islam during the period of the Crusades», Speculum, a Journal of Medieval Studies, 3, VI, 1931, p. 331.

(37) Pedro el Venerable en la Summa contra Haeresis Sarracenorum habla del Profeta como de «un bárbaro entre los bárbaros y un idólatra entre los idólatras», DANIEL, N. Op. Cit., p. 120.

(38) En las crónicas de las cruzadas se habla insistentemente de la utilización de ídolos por los musulmanes y se los describe pormenorizadamente, como en la Gesta Francorum (c. 1100); CARLETON MUNRO, D. Op. Cit. p. 331-332. En la crónica de Fulcher de Chartres, cronista de la Primera Cruzada, se aseguraba que un ídolo de Mahoma había sido situado en el Templo del Señor por los musulmanes, en su Historia Hierosolymitana 26. 9, recogido por STRICKLAND, D. H. Saracens, Demons \& Jews. Making Monsters in Medieval Art. Nueva Jersey, Princeton University Press. 2003, p. 166; Otro cronista, Raúl de Caen, indica en su Gesta Tancredi (c.1131), que este ídolo habría sido visto por Tancredo con sus propios ojos, ofreciendo una descripción fascinante de la supuesta estatua de Mahoma entronizada, de plata maciza, engalanado con joyas y resplandeciente, CAMILLE, M. El ídolo gótico: ideología y creación de imágenes en el arte medieval. Madrid, Akal, 2000, pp. 160-161 y FLORI, J. La guerra santa. La formación de la idea de cruzada en el Occidente cristiano. Trotta, Universidad de Granada. Madrid, 2003, p. 247. 
Meca y en el fetichismo del pueblo árabe preislámico, las acusaciones se justificaron principalmente en la prosternación realizada durante la plegaria musulmana, que se asoció a la adoración de «falsos dioses» y a la veneración de estatuas(39).

La postura de oración musulmana aparece ya perfectamente descrita en el Indiculus Luminosus de Álvaro de Córdoba a mediados del s. IX, con las palabras: «...la oración de los desobedientes es hecha pecaminosamente y con continua encorvadura de la espalda y los repetidos golpes de cabeza, que ostentando su jactancia clavan frecuentísimamente en tierra, no les proporciona la salvación, sino el suplicio eterno»(40). También los cristianos orientales se refieren a la oración musulmana desde los primeros siglos del Islam, estableciendo un vínculo entre ésta y su supuesta idolatría(41). A partir del s. XI vemos proliferar en Occidente las referencias a la ritualidad musulmana como idolátrica. No sólo los escritos clericales latinos recogen esta noción, sino también las transcripciones romance de la poesía oral, acreditando su divulgación y popularidad incluso en los lugares donde no existía contacto directo con los musulmanes. Sorprendentemente, es en las gestas francesas de los ss. XII a XIV donde encontramos más repetida la descripción de una característica reclinación en el rezo musulmán, siempre asociada al culto de ídolos, ante los que se inclinan y humillan(42). Un elemento llamativo resaltado en estos cantares es la inclinación de la cabeza y la elevación de las manos, como en la Canción de Roldán, donde se describe la actitud ante «sus dioses» con frases como «Ambas sus manos levantó hacia arriba» y «Los paganos bajan sus cabezas y sus barbillas/ y sus claros yelmos inclinan tristemente»(43). La elevación de las manos y la reclinación de la cabeza se repiten en estas descripciones épicas(44), aunque también se habla de la prosternación de todo el cuerpo y del arrodillamiento(45).

(39) DANIEL, N. Op. Cit., pp. 284-293.

(40) Á. de Córdoba, Op. Cit., 29, pp. 164-165.

(41) Como Jorge el Monje, Nicetas de Bizancio y Juan Damasceno, en los siglos VIII y IX, DUCELLIER, A. Op. Cit., pp. 196, 210-212.

(42) BANCOURT, P. Op. Cit. Vol. I, p. 406. Así lo vemos en la Canción de Aspremont (s. XII) y en Huon de Bordeaux (s. XIII); donde se indica que los sarracenos se inclinan mucho ante los ídolos: «Et Sarrazin les ont molt enclinés", La Chanson d Aspremont. Chanson de Geste du XIle siècle, París, Librairie Honoré Champion, 1970, Vol. I, v. 2984, p. 96. Huon de Bordeaux, Bruselas, Presse Universitaire de Bruxelles et de France, 1960, vv. 5664-5665, p. 258. En Fierabras (s. XII) se indica que se humillan ante sus ídolos «De Mahonz s aprocha, en vers lui s umelie.»; Fierabras. Les Anciens Poètes de la France, Liechtenstein, Kraus Reprint, 1966, Vol. I, v. 5172, p. 406. En la Canción de Floovant, dos traidores renegados de la fe cristiana se abalanzan a los pies de la estatua grotesca de Mahoma proclamando su poderío y sometiéndose a su protección; Floovant. Les Anciens Poètes de la France, Liechtenstein, Kraus Reprint, 1966, vv. 730-735, p. 23.

(43) La Canción de Roldán, Ed. y Trad. Marcelo Gaya y Delrue. Zaragoza, Librería General. 1959, pp. 163-164, v. 419. Más ejemplos de epopeyas en las que se cita la inclinación de la cabeza, la unión del mentón con el pecho, etc, en, BANCOURT, P. Op. Cit. Vol. I, p. 421, nota 5.

(44) En L Entree d Espagne (s. XIV), el héroe se arrodilla en una mezquita haciéndose pasar por musulmán, explicándose en la misma canción que los paganos se reclinan ante el ídolo de Mahoma «Tres en mi leu dou tenple s est Rolan jenoilé", L Entrée d Espagne. Chanson de Geste Franco-Italienne, París, Fermin Diderot, 1888, vv.13. 318, 13.319, 13.631; 194 et 205.

(45) Como en L Enfance de Guillaume (s. XIII) , v. 1559, «Tuit se coucherent a terre contre lui»; en BANCOURT, P. Op. Cit., Vol. I, 422. 
Comprobamos, así, por la epopeya francesa que fue muy frecuente la atribución de una gesticulación al musulmán orante, consistente en la reclinación del cuerpo, el alzamiento de las manos, el arrodillamiento y los golpes de la cabeza contra el suelo. Los textos de la época demuestran que estos gestos rituales fueron indicio de idolatría tanto en la mentalidad de los clérigos como en el imaginario común, ya que la noción de los musulmanes como idólatras encontró en el canto, la rima y el ritmo su principal canal de difusión.

También el arte pudo servir para divulgar esta idea: algunas figuras románicas repiten este gesto en posible referencia a los infieles tenidos por idólatras. En los canecillos románicos encontramos ciertas figuras que pudieron representar precisamente esta idea, encarnando al enemigo religioso como un pagano que se abandona a cultos idolátricos(46). Así, en la iglesia de San Pedro de Tejada vemos una figura que podría estar adoptando el gesto característico de la plegaria musulmana conforme a las descripciones cristianas de la época (Figura 6a). En la iglesia segoviana de Perorrubio otra esquemática figura repite la postura de prosternación de modo aún más acentuado, con un acusado estiramiento de brazos (Figura 6b). La muy restaurada San Martín de Frómista presenta una figura similar (Figura 6c), que podría constituir una prueba del respeto de los restauradores por el modelo original, si nos atenemos a la presencia de esta representación en otros templos románicos. También en el románico francés vemos aparecer estas figuras, cuyas connotaciones negativas se hacen palpables por su acusada gesticulación y por su presencia en los canecillos, partes marginales del templo. La referencia a los musulmanes idólatras y prosternados en las fuentes francas permite identificar igualmente a la figura de un canecillo de Saint Étienne de Cahors (Figura $6 d)$ como musulmán, aunque el oponente religioso fuera más conocido en estas tierras por los cantares épicos que por la experiencia directa. El alto número de fuentes cristianas y su carácter descriptivo permite así identificar estas figuras prosternadas, resultando perfectamente coherente que el gesto de plegaria, tan distinto entre cristianos y musulmanes, se convirtiera en un rasgo de caracterización visual del sarraceno.

La posibilidad de que la representación románica del caballero victorioso llevara implícita la referencia a los musulmanes como idólatras resulta igualmente coherente a la luz de las fuentes de la época. Sin embargo, necesitamos de indicios propiamente figurativos que nos permitan asegurar que el personaje vencido representa tanto la idolatría como la religión musulmana. Esas evidencias se encuentran en algunos ejemplos de caballero victorioso, que apuntan a una referencia al musulmán como idólatra, sobre el que triunfa el caballero. Y es que las mismas figuras prosternadas de algunos canecillos aparecen, en ocasiones, si-

(46) Tal y como he defendido recientemente; MONTEIRA ARIAS, I. « Retour aux Beatus : Mahomet Pseudo-Prohète et les musulmans idolâtres dans la sculpture romane (IX-XIIle siècle) », en Picturing Prophetic Knowledge: The Prophet Muhammad in Cross-Cultural Literary and Artistic Traditions. En imprenta. 


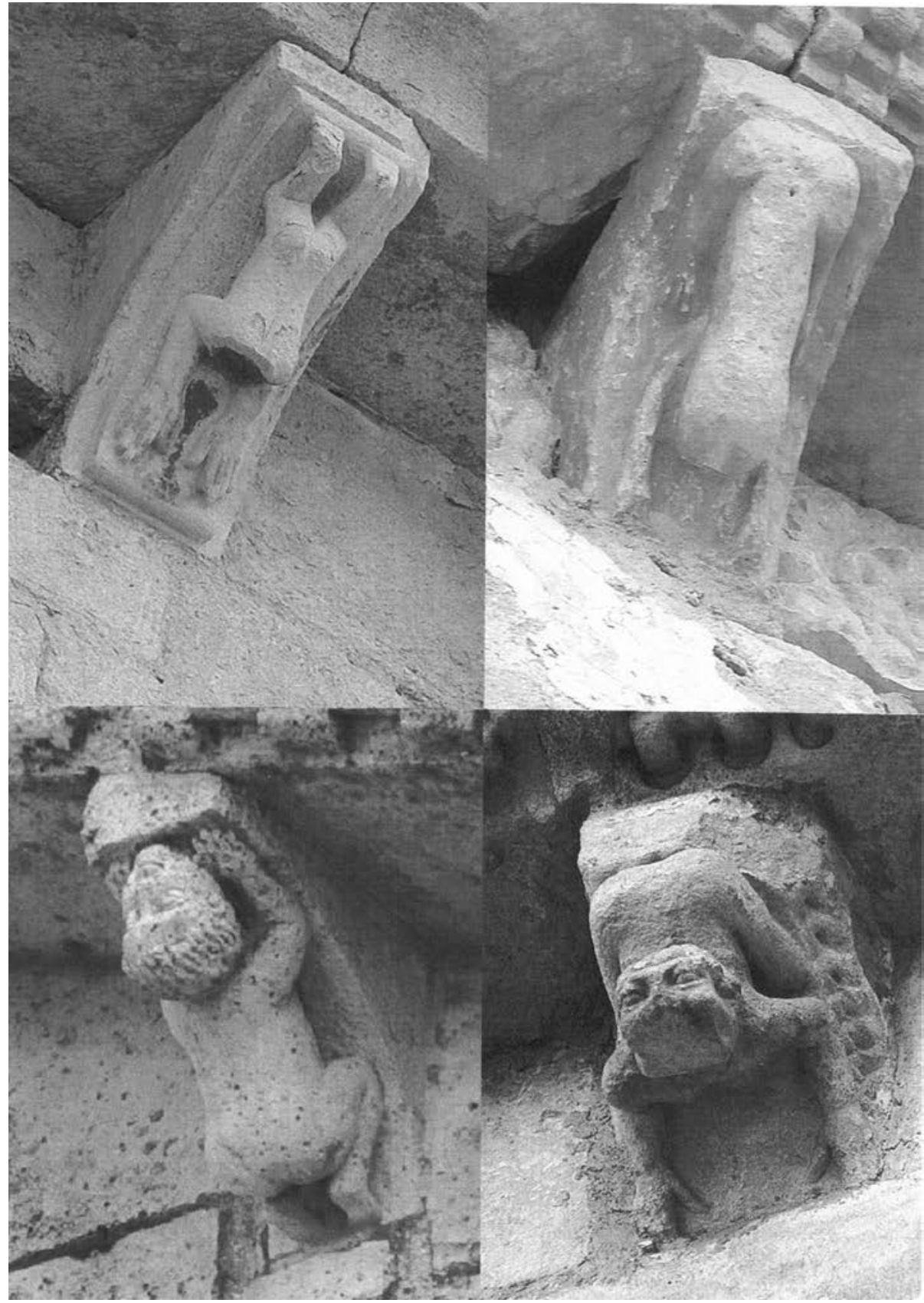

Figura. 6. Canecillos con figuras prosternadas. Por orden de aparición: 6a. San Pedro de Tejada, Puentearenas, primer cuarto del s. XII, Burgos; 6b. San Pedro ad Vincola, Perorrubio, inicios del s. XIII, Segovia; 6c. San Martín de Frómista, 1066-1100, Palencia; 6d. Saint Étienne de Cahors, c. 1135, Lot, Francia. Fotografías: I. Monteira. 


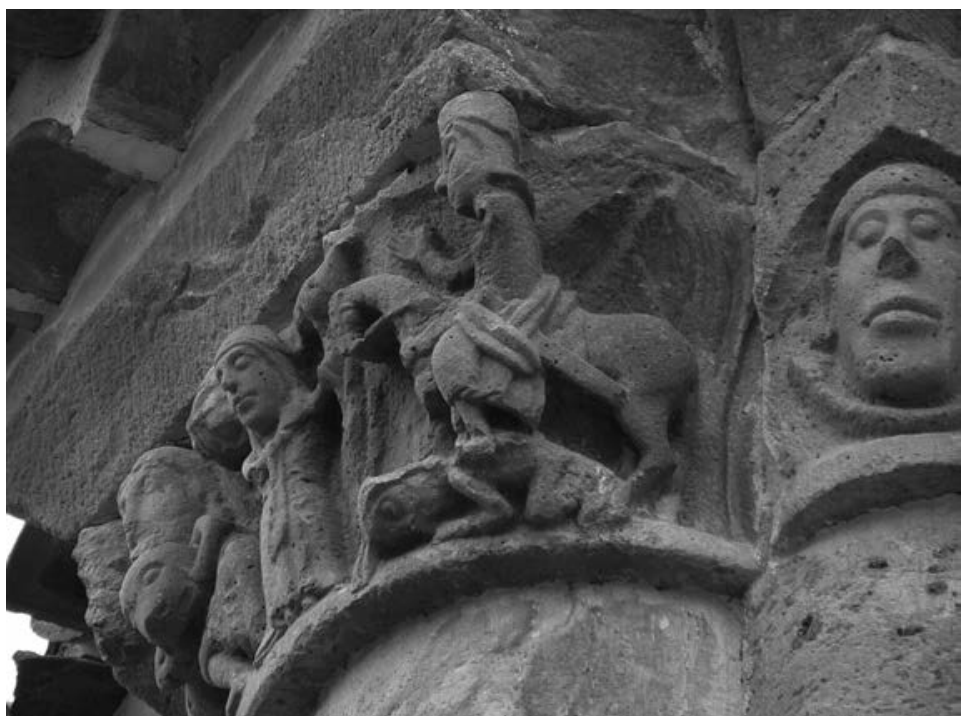

Figura. 7. Capitel exterior de la cabecera de la iglesia de San Lorenzo de Vallejo de Mena, Burgos, finales del s. XII. Fotografía: I. Monteira.

tuadas a los pies del caballero victorioso para hacer más clara la relación entre el prosternado idólatra y el vencido por el jinete.

En un capitel del exterior de la cabecera de la iglesia de San Lorenzo en Vallejo de Mena (Burgos), el personaje vencido bajo el caballero adopta la postura característica de prosternación(47), la misma que es asociada en los textos de la época al gesto de plegaria ritual musulmana (Figura 7). Todo apunta a que la postura característica del personaje vencido pudo identificarlo claramente como un musulmán orante, a la luz de las fuentes citadas. Su postración lo acerca al suelo y agudiza el efecto de derrota bajo los cascos del caballero cristiano, constituyendo una imagen que sintetiza perfectamente la idea del triunfo militar sobre el Islam con la noción de la victoria espiritual sobre la idolatría. En este sentido, la escena viene a encarnar con gran acierto los valores aparejados a la guerra contra el Islam en la cristiandad occidental, concebida como una labor sagrada de dimensiones espirituales(48). Además, la figura situada a la izquierda de este capitel viene a evocar unos valores similares, pues se trata de Sansón desquijarando al león, pasaje insistentemente representado en el románico en alusión al triunfo sobre el Mal

(47) Junto al caballero victorioso, una figura femenina parece representar a la Iglesia triunfante, que separa esta escena de la de Sansón desquijarando al león. Este tema iconográfico resulta muy habitual en el románico y aparece sistemáticamente junto a escenas guerreras y caballerescas, razón por la que podría servir para otorgar un carácter de «lucha contra el Mal» a las escenas de lucha contra el Islam, como defiendo en mi tesis doctoral, tras un profundo análisis (En proceso de publicación, consultable online, http://e-archivo.uc3m.es//handle/10016/8178; pp. 310-321).

(48) Sobre la sacralización de la guerra frente al Islam en la Edad Media; J. Flori, op. cit. 


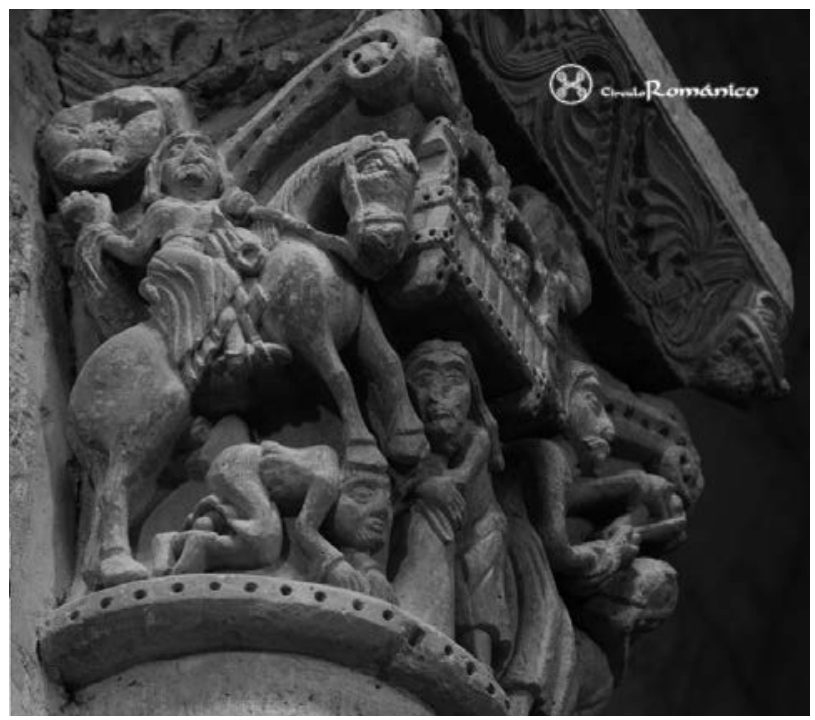

Figura. 8. Capitel izquierdo del arco de triunfo de la iglesia de Santa María la Mayor de Aguilar de Bureba, Burgos, final del s. XII. Fotografía: Cortesía del Círculo Románico.

y sistemáticamente asociado a las escenas de combate entre cristianos y musulmanes(49). La figura femenina que separa ambas escenas podría representar a la Iglesia como una dama que intercambia saludos con el caballero triunfante.

El ejemplo de Vallejo de Mena no es el único en presentar la característica prosternación del vencido, por lo que ésta no puede ser interpretada como fruto de la casualidad ni como un caso aislado. El personaje vencido bajo el caballero victorioso de otra iglesia burgalesa, la de Santa María la Mayor de Aguilar de Bureba, aparece bajo los mismos trazos de prosternación(50) (Figura 8). Se trata del capitel izquierdo del arco de triunfo, que muestra al caballero victorioso galopando sobre la cabeza de otro personaje reclinado. Precisamente, las piernas traseras plegadas y el estiramiento de los brazos hacia adelante coinciden aquí con la

(49) Sansón es un personaje veterotestamentario que formula una prefiguración cristiana y que muere matando en defensa de Yahvé, por lo que constituyó una metáfora muy recurrente para referirse a la lucha contra el Islam. En la literatura, encontramos referencias a este paralelismo en pasajes como el del Poema de Fernán González, donde el héroe guerrea con los musulmanes «a guisa de Sansón»; Poema de Fernán González (Sin ed.) Espasa-Calpe, Madrid, 1973, XVII, p. 78. También Roldán es «parecido a Sansón», Liber Sancti Jacobi, op. cit, Historia de Turpín, Libro IV, Cap. XXV, p. 497. La asociación entre la lucha contra el Islam y el pasaje de Sansón se produce también en términos figurativos en los relieves románicos, pues la escena se sitúa sistemáticamente junto al combate de caballeros, frecuentemente el de un cristiano y un musulmán (como en el Sarcófago de Doña Sancha). Este asunto ha sido objeto de un análisis más pormenorizado en mi tesis doctoral, actualmente en proceso de publicación aunque consultable online, http://e-archivo.uc3m.es//handle/10016/8178 pp. 310-322.

(50) PÉREZ CARMONA, J. Arquitectura y escultura románicas en la provincia de Burgos, Burgos, Seminario Metropolitano, 1959, p. 295, describe este capitel sin ofrecer una interpretación p. 295, describe este capitel sin ofrecer una interpretación ni contextualización del mismo. 


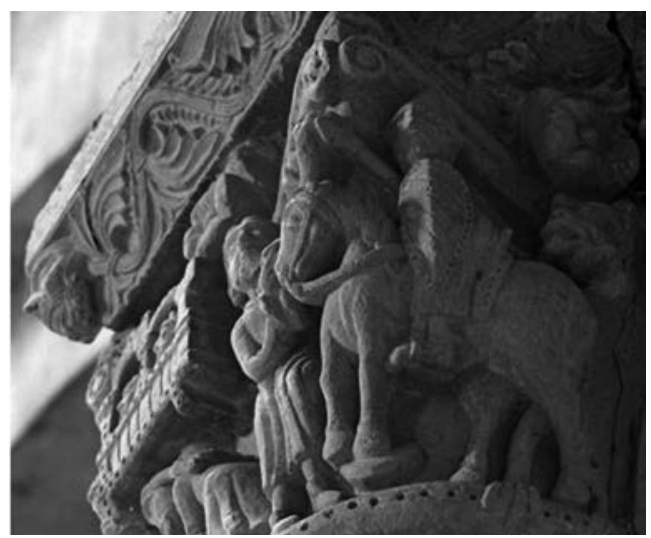

Figura. 9. Detalle del capitel izquierdo del arco de triunfo de la iglesia de Santa María la Mayor de Aguilar de Bureba, Burgos, final del s. XII. Fotografía: I. Monteira.

Figura. 10. Capitel de vano exterior de la colegiata de Santa María de Toro, Zamora, 1160-1240. Fotografía: I. Monteira.

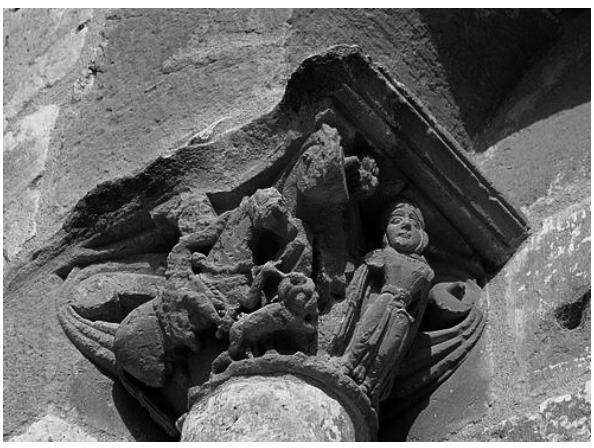

descripción de los musulmanes orantes en las fuentes cristianas evocadas más arriba. La presencia de otra representación guerrera en la parte derecha de este capitel no puede sino ratificar su alusión al contexto bélico de la época (Figura 9). Aunque los limites de extensión de este artículo impiden un análisis en profundidad de esa segunda escena, cabe decir que la imagen refleja los mismos valores guerreros expresados en los poemas épicos respecto a la lucha contra los musulmanes. El caballero, perfectamente equipado con su armadura, se enfrenta a un peón armado con una modesta honda, permitiendo deducir que el primero es un cristiano y el segundo un infiel, de acuerdo con los tópicos de los cantares de gesta, que atribuyen valores morales y sociales a los instrumentos guerreros. En éstos los cristianos suelen llevar espada o lanza y cota de malla, armas dotadas de gran dignidad, mientras los musulmanes se equipan con instrumentos poco convencionales y considerados indignos del caballero cristiano(51). El enemigo religioso

(51) HERMAN, G. «Unconventional arms as a comic device in some chansons de geste», Modern Language Quarterly, 30, 1969, pp. 319-330. Las armas más asiduamente asignadas a los musulmanes son el arco y la flecha, el hacha y la maza. Este aspecto ha sido tratado en mi tesis doctoral, aproximando el estudio de la literatura épica al de la escultura; http://e-archivo.uc3m.es//handle/10016/8178, pp. 177. 
aparece así descrito con un armamento innoble en la poesía de la época para conformar una imagen peyorativa del mismo. Estos detalles pasaron también a los relieves de las iglesias, permitiendo identificar a los musulmanes en el arte por medio de instrumentos guerreros como el arco(52). De este modo, la honda aquí convierte al peón en un enemigo indigno y claramente inferior al cristiano, y encaja en el prototipo literario del infiel. Menos clara resulta la escena central, donde un personaje está atado a una columna a modo de Cristo flagelado, y otros dos aparecen encerrados en un balcón (Figura 8). Si tenemos en cuenta el contexto del conjunto del capitel, aparentemente ambientado en la lucha contra el Islam, podremos especular con la representación de cautivos cristianos que han de ser liberados por los caballeros, tratándose de una importante preocupación del periodo(53).

Al igual que estos dos ejemplos burgaleses, otros relieves románicos hoy mutilados o perdidos pudieron presentar a la figura derrotada en la posición característica de prosternación. Es el caso de un canecillo situado en la Colegiata de Santa María la Mayor de Toro (Zamora), donde el personaje vencido aparece a cuatro patas y podría estar alargando los brazos (Figura 10), aunque su prosternación es menos clara debido a la degradación del relieve. Un gran número de ejemplos del caballero victorioso registrados en España o Francia no recogen la postura de prosternación característica, a pesar de lo cual han sido interpretados con gran frecuencia como representación de la victoria sobre la idolatría. Aunque no todos los ejemplos ofrecen indicios tan claros de su referencia al contexto de la lucha contra el Islam, muchos de ellos portan atributos o aparecen en contextos que podrían apuntar a esa interpretación. Especialmente emblemático resulta el famoso relieve conservado en el claustro de la Catedral de Tudela (Navarra), donde el turbante del personaje vencido sería más elocuente si el conjunto no hubiera sido objeto de restauración (Figura 11). En este sentido, resulta esencial insistir en el análisis de la figura derrotada, pues ésta presenta más variaciones que la del caballero y porta más claves interpretativas que aquél. De hecho, el protagonismo que el caballero ha adquirido respecto al vencido para la historiografía, enredada en dilucidar su identidad, ha impedido en ocasiones avanzar en la interpretación del conjunto.

Diversos autores ya observaron que, con frecuencia, el vencido se aproxima a lo monstruoso y que puede presentar rasgos negroides en su rostro(54), indicio

(52) MONTEIRA ARIAS, I. «Escenas de lucha contra el Islam en la iconografía románica: el Centauro Arquero. Su estudio a través de los cantares de gesta», Codex Aquilarensis, no 22, 2006, pp. 146-171.

(53) Sabemos que en el camino de Santiago se adoraron los restos de numerosos santos liberadores de cautivos de manos musulmanas, como San Leonardo en el Limousin, en cuya iglesia se veían colgados los centenares de grilletes y cadenas de aquellos a los que había liberado; LACARRA, J. M., URIA RIU, J. y Vázquez de PARGA, L. Las Peregrinaciones a Santiago de Compostela. III Vols. Pamplona, Gobierno de Navarra, Iberdrola (ed. facsímil de la realizada en 1948 por el CSIC), 1992 Vol. I, p. 208.

(54) RUIZ MALDONADO, M. «El caballero victorioso en la escultura románica española. Algunas consideraciones y nuevos ejemplos», Boletín del Seminario de Estudios de Arte y Arqueología, XLV, 1979, pp. 271-283. 


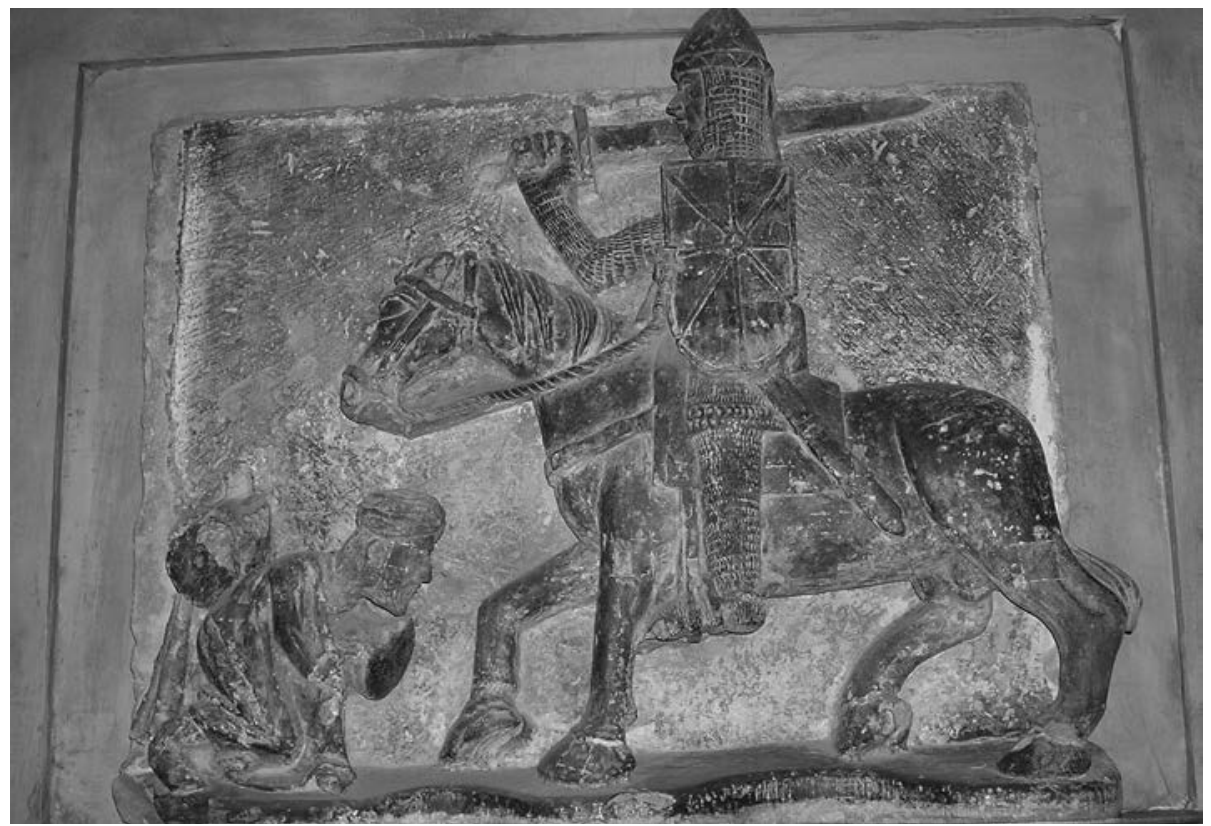

Figura. 11. Relieve conservado en el Museo de Tudela, mediados del s. XIII (identificado como San Jorge o como Sancho VII en las Navas de Tolosa), claustro de la Catedral de Tudela, Navarra. Fotografía: I. Monteira.

que apunta a su identificación como musulmán(55). Los grandes genitales que portan algunas de estas figuras derrotadas, como la de Santa María de Sangüesa en Navarra (Figura 12), se refieren a la victoria sobre la lujuria y establecen nuevos vínculos con la ideología de la guerra sacralizada, ya que un gran número de fuentes hablan de los sarracenos como de seres lúbricos(56). Este mismo rasgo ya llevó a Linda Seidel a interpretar algunos ejemplos franceses como la victoria del caballero cristiano sobre el obsceno musulmán(57).

También en el románico francés encontramos este tema iconográfico bajo los visos de la lucha contra el Islam. En la portada de Sainte Marie de Oloron un jinete en bulto redondo se erige vencedor sobre una figura barbada que, con exaltado gesto, saca la lengua (figs. 13 y 14). El contexto de esta fachada, que apoya su peso sobre las figuras de dos cautivos sarracenos (Figura 15), es el de la procla-

(55) Sobre la asociación de los negros con el Islam por estos siglos ver el magnífico trabajo monográfico de DEVISSE, J. L image du Noir dans I Art Occidental. Vol. II. Des premiers siècles Chrétiens aux «Grandes Découvertes», Bibliothèque des Arts. París-Friburgo, 1979, pp. 53, 72, 81-88.

(56) Sobre la lujuria asimilada a los musulmanes en los textos y en el arte, MONTEIRA ARIAS, I. Op. Cit., pp. 48-87; y en mayor profundidad, el apartado que le dedico en mi tesis doctoral, http://e-archivo.uc3m.es//handle/10016/8178, pp. 342-361.

(57) SEIDEL. L. Op. Cit. 1981, pp.67 y ss. Un capitel del claustro de la colegiata de Santa Juliana, en Santillana del Mar, muestra también al caballero victorioso sobre un personaje de genitales aparentemente hipertróficos. 
Figura. 12. Parte de la fachada oeste de la iglesia de Sta. María la Real, Sangüesa, Navarra, finales del s. XII o inicios del XIII. Fotografía: I. Monteira.

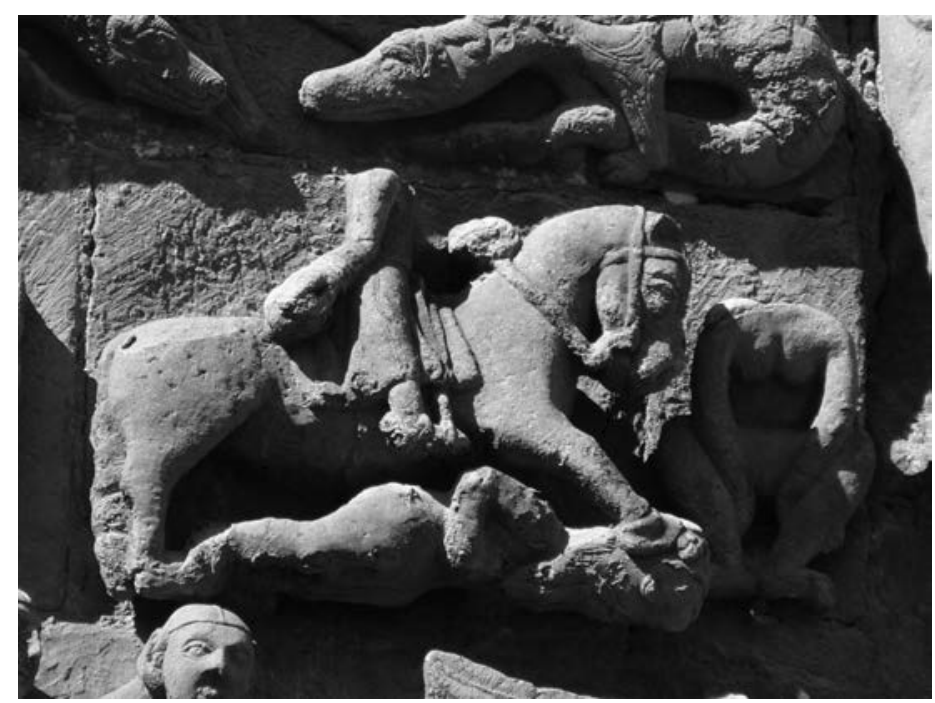

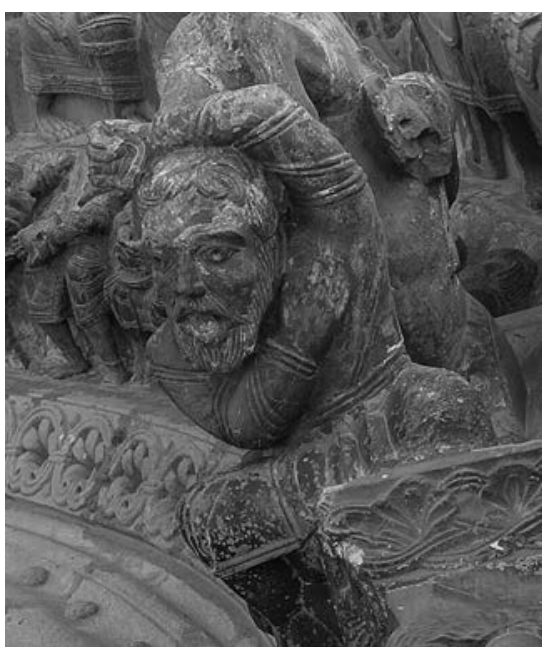

Figura. 13. Relieve situado a la derecha de la fachada oeste de la Catedral de Sainte Marie, Oloron Sainte-Marie, Pyrénées Atlantiques, Francia. Fotografía: I. Monteira.

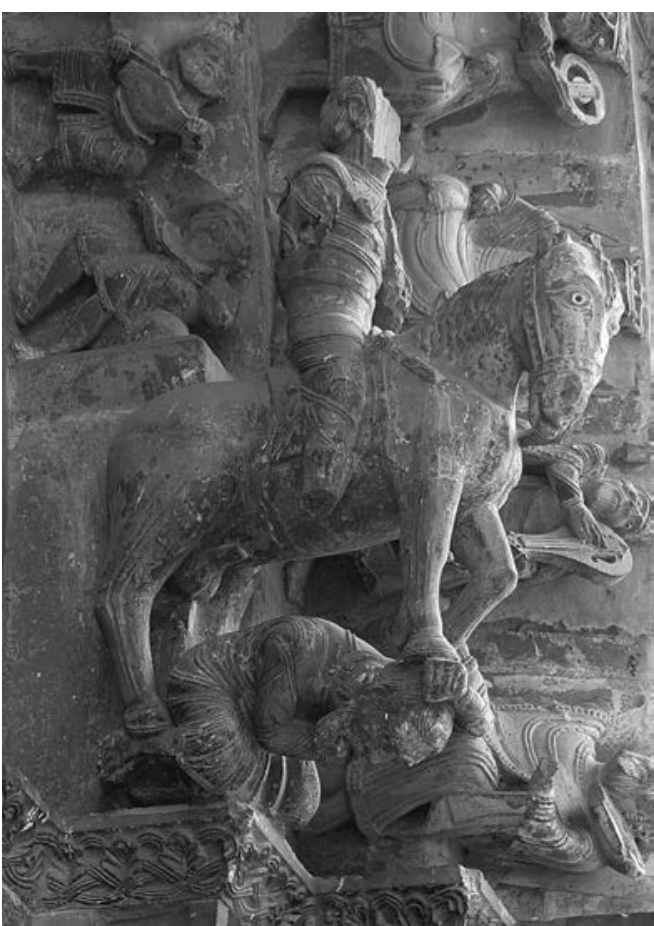

Figura. 14. Relieve situado a la derecha de la fachada oeste de la Catedral de Sainte Marie, Oloron Sainte-Marie, Pyrénées Atlantiques, Francia. Fotografía: I. Monteira. 


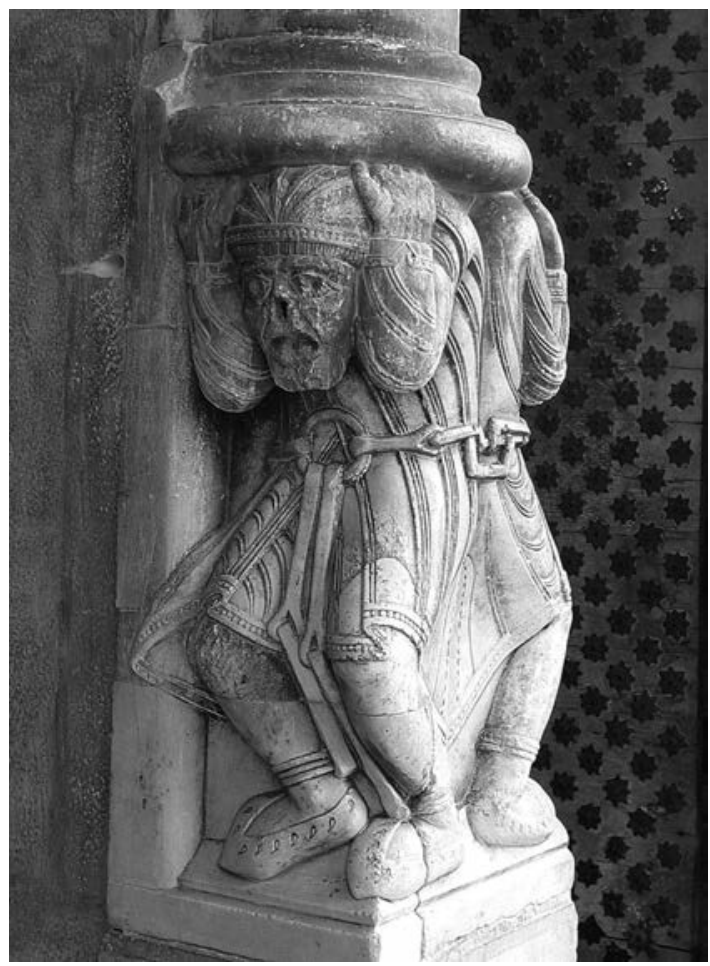

Figura. 15. Parteluz de la fachada oeste de la Catedral de Sainte Marie, Oloron Sainte-Marie, Pyrénées Atlantiques, Francia. Fotografía: I. Monteira.

mación victoriosa del cristianismo frente al Islam(58). Como el enemigo vencido, los cautivos atlantes sacan ostensiblemente la lengua, lo cual establece un vínculo entre sendas representaciones, apuntando probablemente a su falsedad y blasfemia(59).

Las aportaciones y ejemplos precedentes ponen en evidencia la estrecha relación existente entre la propagación de la figura del caballero victorioso y la ideología de la guerra contra el Islam. Conforme profundizamos en el contexto histórico, artístico y de mentalidad en que se inscribe esta representación, resulta más improbable su alusión restringida al antiguo emperador romano. Por otro lado, si re-

(58) Estas figuras han sido objeto de diversos análisis que han llevado a demostrar su identificación con musulmanes, tanto por su indumentaria y rasgos fisonómicos como por el contexto en que se encargó erigió esta catedral; BARTAL, R. «Le programme iconographique du portail occidental de Sainte-Marie d Oloron et son contexte historique", Les Cahiers de Saint Michel de Cuxa, 1987, 18, pp. 95-113.

(59) Sobre el gesto de sacar la lengua en alusión al embuste MONTEIRA ARIAS, I. La influencia islámica en la escultura románica de Soria. Una nueva vía para el estudio de la iconografía en el románico. Monográfico. Cuadernos de Arte e Iconografía, no 29. Fundación Universitaria Española. Madrid, 2005, p. 163; y en referencia al a blasfemia, más pormenorizadamente ver mi tesis doctoral. http://e-archivo.uc3m.es//handle/10016/8178, pp. 415-422. 
gresamos sobre las fuentes empleadas por Mâle y Adhémar para justificar el culto a Constantino en época plenomedieval, comprobamos que su identificación con la estatua de Marco Aurelio es, en realidad, negada por las fuentes ilustradas de la época, tales que el Mirabilia Urbis Romae (c. 1142): «Laterani est quidam caballus ereus qui dicitur Constantini. Sed non est ita»(60). Esta fue la guía de peregrinación a Roma más copiada en la Edad Media, por lo que, sin duda, influyó en las informaciones existentes sobre los monumentos romanos en el resto de Europa, al menos en los círculos monásticos y clericales -responsables, a su vez, de proyectar las imágenes de los templos. Sorprende que Mâle se sirviera de esta fuente para probar la antigua existencia de un bárbaro enano bajo el caballo de Marco Aurelio y silenciara la negación de la identidad constantiniana(61). La guía ofrece, en realidad, una interpretación diferente para la estatua de bronce, a la que identifica con un soldado de gran belleza y valor que salvó a Roma del asedio de un poderoso rey venido de Oriente, que acosara al pueblo romano con estragos y guerra(62). Aunque no hay rastro del ideal de la guerra sacralizada contra el Islam, pues el autor es consciente de la antigüedad de la estatua, la leyenda evocada por la guía se corresponde en mayor medida con la noción de un defensor de Occidente frente a un enemigo oriental(63). Otra guía posterior, la escrita por el viajero inglés Gregorio, De Mirabilibus Urbis Romae (c. 1200), señala igualmente que la estatua tiene una identidad distinta a la de Constantino, a decir de cardenales y clérigos, contra la consideración de algunas gentes, ofreciendo dos posibles atribuciones entre las que se reitera la del héroe local(64). El historiador Jean Adhémar llegaría a ampararse en esta última fuente, que niega la identidad constantiniana, para alegar que la imagen dejó de representarse bruscamente a principios del s. XIII por estas dudas sobre su identidad(65), pero, como hemos visto, éstas ya estaban reflejadas en la primera guía de Roma de 1142. Además, un gran número de ejemplos románicos del caballero victorioso fueron esculpidos precisamente en el

(60) Mirabilia Urbis Romae. Ed. I. Ferrante Corti, Collana Romana Vol. IV, Albano Laziale, Strini, 1930, pp. 39-40, 102-103.

(61) MÂLE, E. Op. Cit, p. 250. El autor sólo recoge el testimonio de Benjamín de Tudela del s. XII para la identificación de Constantino en la estatua de Marco Aurelio, Ídem., p. 247.

(62) «Rex potentitissimus de orentis patribus Italiam venit», Mirabilia Urbis Romae, Op. Cit., pp. 3940, $102-103$.

(63) El rey oriental, de pequeñísima estatura según la guía, "qui erat parvissime persone», sería el enemigo representado bajo la estatua romana; Ídem., pp. 41-42, 104-105.

(64) Este sería Marco, que derrotó a un rey que asedia la ciudad con sus poderes mágicos El maestro Gregorio le dedica especial atención a esta estatua, aproximadamente un quinto de su narración descriptiva, ofreciendo dos interpretaciones de la misma, entre la que se cuenta la del vencido como de un mago moribundo, rey de Misena (Rex Misenorum) que atacó la ciudad con su necromancia y fue por fin vencido por un héroe de nombre Marco, trayendo un inmenso botín para la ciudad de Roma, De Mirabilibus Urbis Romae, en Il fascino di Roma nel Medioevo. Le "Meraviglie di Roma" di maestero Gregorio. Estudio y Ed. C. Nardella. Roma, Viella, 1997, p. 83. El maestro Gregorio dice que algunas gentes de Roma lo identifican con Constantino, pero que cardenales y clérigos lo identifican con Marco o Quinto Quirino, De Mirabilibus Urbis Romae, IV, 191r-193r, pp. 146-151, señala que en este tiempo la estatua ya se había trasladado al palacio del papa. La editora señala que en textos anteriores al Mirabilia Urbis Romae (c. 1142) se había identificado la estatua con Constantino, íbidem.

(65) Cuestionada por personajes como Honorio III (m. 1227), ADHÉMAR, J. Op. Cit. p. 216. 
s. XIII, especialmente en el ámbito hispano, por lo que no cabe hablar de la brusca desaparición del motivo.

De este modo, la creencia en que la estatua romana se correspondía con el supuesto primer emperador cristiano estuvo sólo extendida entre las clases populares, concretamente entre los peregrinos procedentes de Roma. Pero los caballeros victoriosos aparecen en los templos del camino jacobeo y no del romano, mientras los programas escultóricos románicos dependieron de la planificación de monjes y clérigos(66), por lo que debemos cuestionar la identidad constantiniana del caballero románico a la luz de las fuentes que atestiguan su negación. Cabe igualmente dudar de la existencia de una identidad única y excluyente del caballero victorioso medieval, que en ocasiones pudo gozar de un significado colectivo y no individual. La propia identificación de la dama con la Iglesia concede una gran versatilidad al caballero, permitiéndole encarnar a cualquier defensor de la fe por la espada, o bien a todos ellos. El jinete triunfante que analizamos fue, así, susceptible de representar tanto a Constantino, a Carlomagno y a Santiago, como a los reyes y héroes que en tiempos románicos encarnaron los ideales de Reconquista y cruzada. Y ello se debe a que los primeros sirvieron de modelo e inspiración para los segundos.

La comprensión de Constantino en un sentido histórico por parte de algunos estudiosos choca radicalmente con la percepción y la sensibilidad que se observa respecto a los personajes del pasado en las fuentes escritas y figurativas de los siglos centrales de la Edad Media. Sabemos que la figura de Constantino fue evocada en el proceso de sacralización de la guerra contra los musulmanes desde el principio, pues su lema victorioso era empleado contra al-Andalus ya por los monarcas asturianos(67). Pero el emperador adquirió especial vigencia a finales del s.

(66) Como todos los programas iconográficos románicos. Un magnífico estudio al respecto en WIRTH, J. Op. Cit.

(67) Tanto las cruces asturianas como el Crismón románico se relacionan con el lábaro constantiniano. Eusebio de Cesarea relataba el sueño de Constantino antes de la batalla y su lema Hac Vince para designar al crismón, «trofeo de Salvación» y «trofeo de inmortalidad», idea que sería recuperada en la Crónica de Alfonso III en la que se definen los aspectos políticos y religiosos de la Reconquista: el discurso atribuido a Pelayo en Covadonga repite fórmulas similares que se perpetuarán en las crónicas de Nájera, del Arzobispo Pelayo y la Silense, BARTAL, R. "The survival of early christian symbols in 12th Century Spain», Príncipe de Viana, XLVIII, 1987, no 181, p. 303, p. 303.

(68) Reliquia más santa de Jerusalén cuyo hallazgo se atribuía a la madre del emperador, Elena, transformándola él en trofeo de victoria sobre los enemigos de la Iglesia. Los cruzados creían ir a rescatar el Santo Sepulcro y la Vera Crucis de manos musulmanas, alegando la profanación de los santos sitios por los infieles; CURZI, G. «La croce dei crociati: segno e memoria». En La croce: iconografia e interpetazione (secoli I - inizio XVI), Ed. B. Ulianich y U. Parente. Nápoles, De Rosa, 2007, p. 128, p. 128.

(69) Por esa razón, Curzi entiende estas imágenes como la representación de Constantino en tanto que directa evocación de las cruzadas ídem., p. 129. Interpreta la representación y recuperación de la estatua ecuestre de Constantino en algunas fachadas aquitanas como alusión a Constantino y a Carlomagno, en tanto que campeones victoriosos de la lucha contra el paganismo y como imagen directamente evocadora de la cruzada, «Stereotipi, metafore e pregiudizi nella rappresentazione di cristiani e musulmani in epoca crociata». En Medioevo mediterraneo: l'Occidente, Bisanzio e l'Islam. Centro di Studi Medievali, Università degli Studi di Parma; Fondazione Monte di Parma. Ed. A. C. Quintavalle. Milán, Electa, 2007, p. 534-545. 
XI en relación con las cruzadas y con el culto a la Vera Crucis, la santa reliquia que sirvió de pretexto para la toma de Jerusalén(68). En un sentido simbólico, el valor profiláctico atribuido a la cruz en los tiempos de la Primera Cruzada señalaba a cada príncipe cristiano portador del mismo como nuevo Constantino(69).

También Carlomagno fue un personaje revivido y revisado en tiempos románicos a fin de servir de modelo en la lucha contra el Islam, adquiriendo un rol principal en el contexto de las cruzadas peninsulares y orientales. La leyenda inventada por la Canción de Roldán antes de finales del s. XI, lo convierte en el restaurador del cristianismo en Hispania y en el vencedor sobre el rey musulmán de Zaragoza. La Historia de Carlomagno (c. 1130), citada anteriormente, atestigua que la leyenda sobre el monarca franco no sólo caló en los ambientes populares sino en todos los estratos de la sociedad, y sus legendarios triunfos sobre los sarracenos fueron incluso esgrimidos en la predicación de la Primera Cruzada por Urbano II en Clermont-Ferrand (1095)(70). Además, en el s. XII se elabora una narración que sitúa a Carlomagno en Tierra Santa(71), sirviendo para vincular su figura con la de Constantino(72). De este modo, aunque Carlomagno nunca luchó contra los andalusíes en la Península ni contra los musulmanes orientales, la leyenda lo convirtió en un auténtico emblema de la guerra contra el Islam, mientras Constantino se transformaba en otro modelo de prestigio, aún más antiguo, en el que amparar la guerra sacralizada. Vemos así que la identidad constantiniana o carolingia del caballero victorioso no cambia en gran medida el significado de la figura dentro de los parámetros de mentalidad de tiempos plenomedievales, evocando ambos los ideales de la lucha contra el Islam(73). La concepción imperial del monarca que ocupa tierras al Islam subyace tras estos mitos, asociándose tanto a Carlomagno(74) como a ciertos reyes hispanos tales que Alfonso VII, autoproclamado Imperator por sus labores de «Reconquista»(75).

(70) L. Seidel, Op. Cit. 1981, p.71 ; J. Flori, op. cit., pp. 15-16.

(71) Esta es la Descriptio qualiter Karolus Magnus clavum et coronam Domini a Constantinopoli Aquisgrani detulerit; MAINES, C. "The Charlemagne Window at Chartres Cathedral: New Considerations on Text and Image", Speculum, v. 52, 4, 1977, p. 803, nota 3, texto publicado por Gerhard Rauschen, Die Legende Karls des Grossen im XI und XIII. Jahrhundert. Publikationen der Gesellschaft für rheinische Geschichtskunde 7 (Leipzig 1890), pp. 103-125, siguiendo dos manuscritos: París BN, MS lat. 12710 y Viena, Hofbibliothek MS 3398, datados en el s. XII.

(72) Según esta historia, ilustrada en una vidriera de la catedral de Chartres (c. 1225), el emperador romano habría tenido un sueño premonitorio en el que se le revelaba que Carlomagno vendría un día para combatir a los musulmanes, arrebatándoles el control de Jerusalén. La noticia sobre este sueño habría decidido al monarca franco a partir hacia Tierra Santa; MAINES, C. Op. Cit., pp. 805-806, Figura 2, panel 3 y 5 . En la vidriera de Chartres aparece Carlomagno llegando a Constantinopla y siendo recibido por Constantino. La fórmula del sueño, recurrente en las narraciones hagiográficas, sirve también para explicar la campaña de Carlomagno en España contra los musulmanes a instancias de Santiago el Mayor que se le aparece por tres veces de ese modo; Liber Sancti Jacobi, Op. Cit., Cap. I, pp. 413-415.

(73) El emperador franco fue concebido como un «nuevo Constantino" desde su propia época y especialmente en tiempos románicos. Sobre la asociación de Carlomagno y Constantino, SEIDEL, L. Op. Cit. 1976, “Constantine...», pp. 237-239; DUBY, G. La época de las Catedrales. Arte y Sociedad 9801420. Madrid, Cátedra, 1993, p. 24; RUIZ MALDONADO, M. Op. Cit. «El caballero victorioso..., pp. 271 272. 
También Santiago emerge en esta época como una vieja figura reinterpretada, aunque alejada en origen del contexto de la lucha contra el Islam -tanto cronológicamente como en el propio carácter del apóstol que nada tuvo de guerrero. Pero se le atribuyó una leyenda hacia los ss. X y XI que sólo cobraba un sentido en el tiempo presente, y fue en virtud de esa nueva historia heroica y actualizada, como el apóstol se convirtió en estandarte de guerras y en meta de peregrinaciones(76). El Santiago guerrero de época plenomedieval constituye un ejemplo principal de la resucitación de viejas figuras con el fin de hacer extensivo su prestigio a la nueva causa bélica que se le asigna.

Es así como la autoridad de antiguos modelos cristianos -Constantino, Santiago, Carlomagno... - permitió ensalzar la lucha contra el Islam por medio de narraciones inventadas, apariciones milagrosas en el fragor de la batalla y en los sueños de renombrados reyes. La implicación de antiguos santos en la nueva causa guerrera confirmaba la pertinencia dogmática del conflicto, ratificaba que se trataba de la lucha contra un mal universal y atemporal, contra un mal absoluto. El motivo románico del caballero victorioso permitió trasponer estas nociones, tan arraigadas en el pensamiento, a los muros de las iglesias. La difusión de esta representación responde, por tanto, a la enorme relevancia social que adquiere el caballero al servicio de la Iglesia, el miles christi, tanto en su dimensión de santo o héroe como en su condición mundana, pues también los guerreros cruzados y reconquistadores pudieron adquirir la santidad o el martirio por medio de sus acciones(77).

Los santos caballeros, glorificados en las leyendas y en las paredes de los templos, permitieron legitimar la unión entre Iglesia y asuntos de Estado, entre religión

(74) Incluso Constantino aparece formando parte del cortejo guerrero de Carlomagno en la Historia de Pseudo Turpín, donde figura junto a otros personajes históricos bajo el apelativo "Constantinus prefectus romanus» o "Constantinus rex romanus», y se enfrenta al personaje Ferragut; SEIDEL, L. Op. Cit. «Constantine...», pp. 238-239.

(75) Alfonso VII se hacía coronar como totius Hispaniae Imperator en la primavera de 1135 con el respaldo del papa, erigiéndose como el mayor poder cristiano peninsular y como el que había de liderar las acciones frente al Islam; LADERO QUESADA, M. A. (coord.) La Reconquista y el proceso de diferenciación política (1035-1217). Historia de España Menéndez Pidal. Vol. IX, Madrid, Espasa-Calpe, 1998, pp. 410-411.

(76) Es en la Crónica de Sampiro (ss. X-XI) cuando el patrón de España surge por primera vez ofreciendo su ayuda a los contingentes cristianos, pero sin intervenir directamente en la contienda. Será un siglo más tarde, en la Crónica Silense cuando el Santo aparece en la mítica batalla de Clavijo, BARKAI, R. Op. Cit., pp. 114-116, 236; aunque el relato más antiguo de la aparición de Śantiago en Clavijo es el Privilegio de los Votos, que suele datarse a finales del s. XI; CABRILLANA CIÉZAR, N. Op. Cit., p. 74. Respecto al mito de Santiago como patrón de Hispania y motor de las peregrinaciones al camino de Santiago, parece que fue Beato de Liébana quien le dio forma a finales del s. VIII en su himno O Dei Verbum. Se cree que buscaba en el patronazgo de Santiago el Mayor el principio de unidad para la Iglesia y el Reino de Asturias, BEATO DE LIÉBANA, Obras completas de Beato de Liébana. Eds. J. G. Echegaray, A. del Campo y L. G. Freeman. Madrid, Estudio Teológico de San Ildefonso-Biblioteca de Autores Cristianos. 1995, Introducción. p. XL.

(77) Sobre la consideración de los caídos en la lucha contra el Islam como mártires, en relación con las indulgencias características de la guerra sacralizada contra el Islam, ver FLORI, J. Op. Cit. pp. 26-27, 154, 246. 
y guerra. El estrecho vínculo existente entre la sacralización de la guerra y la figura del santo armado constituye la razón de ser del tema románico que ha sido objeto de estudio en estas páginas. Pero los indicios que llevan a vincular de modo concluyente al caballero victorioso románico con la ideología de las campañas emprendidas contra el Islam son propiamente figurativos. El análisis de la postura de prosternación adoptada por la figura vencida constituye la prueba más convincente del significado antiislámico del caballero victorioso románico, corroborado a su vez por las fuentes textuales. Estas nociones prevalecen sobre la eventual identidad constantiniana de la figura -o incluso carolingia o jacobea- que pudo ser latente o patente, pero siempre supeditada al contexto de guerra sacralizada que hizo proliferar esta representación. 
